\title{
The influence of KIBS-client interactions on absorptive capacity-building for environmental innovation
}

DOI:

10.1108/EJIM-01-2019-0026

\section{Document Version}

Accepted author manuscript

Link to publication record in Manchester Research Explorer

\section{Citation for published version (APA):}

Pace, L., \& Miles, I. D. (2019). The influence of KIBS-client interactions on absorptive capacity-building for environmental innovation. European Journal of Innovation Management. https://doi.org/10.1108/EJIM-01-20190026

\section{Published in:}

European Journal of Innovation Management

\section{Citing this paper}

Please note that where the full-text provided on Manchester Research Explorer is the Author Accepted Manuscript or Proof version this may differ from the final Published version. If citing, it is advised that you check and use the publisher's definitive version.

\section{General rights}

Copyright and moral rights for the publications made accessible in the Research Explorer are retained by the authors and/or other copyright owners and it is a condition of accessing publications that users recognise and abide by the legal requirements associated with these rights.

\section{Takedown policy}

If you believe that this document breaches copyright please refer to the University of Manchester's Takedown Procedures [http://man.ac.uk/04Y6Bo] or contact uml.scholarlycommunications@manchester.ac.uk providing relevant details, so we can investigate your claim.

\section{OPEN ACCESS}




\section{eEmerald $\begin{aligned} & \text { European Journal of } \\ & \text { Innovation Management }\end{aligned}$}

The influence of KIBS-client interactions on absorptive capacity-building for environmental innovation

\begin{tabular}{|r|l|}
\hline Journal: & European Journal of Innovation Management \\
\hline Manuscript ID & EJIM-01-2019-0026.R2 \\
\hline Manuscript Type: & Original Article \\
\hline Keywords: & $\begin{array}{l}\text { environmental innovation, absorptive capacity, client, B2B, Knowledge } \\
\text { intensive business services }\end{array}$ \\
\hline \multicolumn{2}{|l}{} \\
\hline
\end{tabular}




\section{$1 \quad$ Structured Abstract}

2 Purpose: Firms need to develop absorptive capacities to effectively source and exploit

3 knowledge relevant to environmental behaviour for their own innovation activity. Business-to-

4 business interactions can represent a significant route through which knowledge and resources

5 about environmental innovations are transferred along the supply chain. The purpose of this

6 paper is to explore how firms exploit business partnerships in order to build capacity for

7 environmental innovation. In order to do so, it investigates two elements of B2B interactions -

8 partner alignment and compatibility - and their influence on absorptive capacity-building.

9 Design/methodology/approach: This paper is based on a qualitative interview study of 10 knowledge intensive business services (KIBS) operating in the environmental goods and 11 services sector and their clients involved in adopting environmental innovations. Matched pairs 12 of engineering consulting firms and their clients - tourism accommodation establishments were selected as a sampling frame in order to study the influence of partner alignment and 14 compatibility on the exchange of environmentally-relevant knowledge and competencies.

15 Findings: The findings show that the synergistic attributes of business partners influence absorptive capacity-building and give rise to different patterns of interaction of KIBS with their

17 client. The B2B interactions investigated are characterised by alignment along multiple objectives about the relevance of environmental behaviour. Furthermore, the compatibility of the partners' competences is a key determinant of environmental innovation outcome.

20 Practical implications: The study highlights the role of managers in identifying and selecting those business partnerships that accrue greater potential benefit for accessing resources and competencies for eco-innovation. 
23 Originality/value: The study contributes to the literature on absorptive capacity and

24

25 innovation by demonstrating how B2B interactions - in this study, the interaction of KIBS with their clients - influence the capacity of firms to adopt environmental innovations which is an area of study that deserves further attention.

\subsection{Introduction}

Firms are increasingly resorting to cooperation with external partners when implementing environmental innovations (Cainelli et al., 2015; de Marchi and Grandinetti, 2013; del Río et al., 2015). In particular, business-to-business relations are becoming a locus for information and competences about environmental innovations to be exchanged amongst partner firms (Fraj et al., 2013; Hofmann et al., 2012; Liu and Zhang, 2014). This study explores how resources and competencies about environmental innovation are transferred between firms in a B2B context. There may be specific challenges that firms encounter when implementing environmental innovations, including sourcing relevant competencies about environmental technologies or practices, which are often very different from the technology and market domains within which they usually operate (Cainelli et al., 2015; de Marchi and Grandinetti, 2013). The larger degree of novelty and uncertainty associated with environmental innovations also makes them more knowledge- and information-intensive than many other innovation types.

This study draws from the resource-based view of the firm, which underscores the contribution of resources and capabilities for value-creating activities, such as the development of new products and services that are more able to meet customer demands and the identification of new technological opportunities (Eisenhardt and Martin, 2000). In particular, firms need to develop absorptive capacities to source and exploit knowledge from external sources for their innovation activity (Cohen and Levinthal, 1990; Dyer and Singh, 1998; Ferreras-Méndez et al., 
47 2016). The literature on dynamic capabilities has analyzed how a firm's structural and

organizational characteristics influence absorptive capacity, focusing on aspects such as prior available knowledge, $R \& D$ capability and the availability of skilled personnel (Cohen and Levinthal, 1990; Lane et al., 2006). The extent to which firms exploit B2B interactions in order to gain access to resources and competences to build absorptive capacity for environmental innovation remains under-researched (Liu and Zhang, 2014; Nyaga et al., 2010).

Firms source external knowledge through several routes. Research on knowledge intensive business services (KIBS) and innovation, shows that KIBS act as brokers between the client's resources and capabilities and external knowledge bases and they can be a source of innovation for their clients (Cabigiosu and Campagnolo, 2019; den Hertog, 2000; Tether and Tajar, 2008). Moreover, KIBS have also been shown to be a primary source of environmental knowledge amongst "green" innovators (de Marchi and Grandinetti, 2013). Aarikka-Stenroos and Jaakkola (2012) are among those who view the KIBS-client interaction as a "collaborative process" (p.17), in which each partner contributes its competences and knowledge for joint problemsolving. In practice, KIBS can face challenges in effectively assimilating and transferring knowledge, related to how well they understand the client's needs and expectations (den Hertog, 2000; Miles, 2005; Rodriguez et al., 2017). Likewise, clients vary in their knowledge needs and range of competencies which influence their ability to tap into this specialist knowledge (Castaldi et al., 2013; Eisingerich et al., 2009; Ferreras-Méndez et al., 2016). This study addresses a gap in understanding how elements of the KIBS-client interaction influence knowledge transfer for absorptive capacity-building in connection with knowledge about environmental innovation. The study makes the following contributions to the literature.

First, it advances an understanding of absorptive capacity in a B2B context, by considering a specific source of external knowledge coming from a selected partner. Studies of the role of B2B interactions have tended to focus separately on the buyer's or the supplier's perspective 
72 (Aarikka-Stenroos and Jaakkola, 2012; Sáenz et al., 2014). This study takes the perspective of both partners - the KIBS and the client - in understanding those elements of the interaction

that contribute to absorptive capacity-building for environmental innovation. Second, the study explores how specific elements of the interaction influence absorptive capacity for environmental innovation. KIBS-client interactions are heterogeneous, involving differences in the partners' skills, knowledge bases, motivations to interact and approaches to innovation (Cabigiosu and Campagnolo, 2019; Eisingerich et al., 2009; Miles, 2012). Building on the literature on KIBS and their role in client innovation, the study focuses on two elements contributing to the process of knowledge transfer amongst business partners: (1) the goals and objectives for implementing environmental innovations, and the extent to which these goals are aligned amongst the partners; and (2) the compatibility of the partners' competencies for environmental innovation. These elements are discussed further in the literature review.

Studies of the adoption of environmental innovations have tended to focus on polluting manufacturing industries, such as the chemical or the automotive industries, either because these are subject to stricter environmental regulation and stakeholder demand or because of their high potential for introducing environmental innovations (Díaz-García et al., 2015). This study investigates service industries which have received much less attention, perhaps because they are perceived as less-polluting. However, Cainelli and Mazzanti (2013) demonstrate that services contribute an important share of carbon dioxide emissions and envision that in future, they will face stricter environmental controls. Amongst the service industries, tourism is facing pressures to shift towards more sustainable practices (Molina-Azorin et al., 2009; WEF, 2017). As with firms in other low- (and medium-) tech industries, tourism businesses are generally characterised by limited internal capabilities for research and innovation, using non-R\&Drelated activities when trying to improve their overall performance. The presence of weak internal resources for innovation makes tourism firms reliant on external knowledge sources to 
97 build an absorptive capacity for innovation (Alvarez and Iske, 2015; Martínez-Pérez et al.,

98

99

100

101

102

103

104

105

106

107 2019); this is likely to be the case for the adoption of environmental innovations as it is for other aspects of business performance. In this study, we examine the interaction of tourism accommodation establishments with engineering consulting firms and how this facilitates the adoption of environmental innovations mainly in energy and water management.

Environmental innovations, hereafter referred to as eco-innovations, are generally characterized by their reduced impact on the environment - being either less resource demanding or producing lower waste outputs. They are broadly described in terms of combinations of such elements as: type (product vs. process; technological vs organisational); novelty (incremental vs. radical); and systemic nature (end-of-pipe vs. clean tech, CarrilloHermosilla et al., 2010; Hellström, 2007). Innovations are not limited to new to the market products or services. We adopt the definition of eco-innovation as "new to the firm" innovations, whether developed internally or adopted from the outside (del Río et al., 2015).

The paper is organised as follows. Section 2 first reviews the literature on absorptive capacity with a focus on low-tech sectors and then it characterizes the elements of the KIBS-client interaction that this study is based upon and that influence absorptive capacity-building. The methodology in Section 3 describes the criteria for sample selection. Section 4 presents the results and an analysis of the findings. A discussion in the final section considers implications for managers and policymakers and directions for future research.

\section{Literature Review}

\subsection{Elements of absorptive capacity}

Absorptive capacity underscores a firm's dependence on external knowledge sources for the innovation process. Cohen and Levinthal (1990) define a firm's absorptive capacity as the "ability to recognize the value of new, external information, assimilate it, and apply it to 
121

122

123

124

125

126

127

128

129

130

131

132

133

134

135

136

137

commercial ends" (p. 128). Three elements of absorptive capacity are highlighted. One is the ability of a firm to recognize new external knowledge - this is exploratory learning. The second is the ability to assimilate or combine new knowledge with existing knowledge or transformative learning. The third is the application of such assimilated knowledge for innovation - exploitative learning (Lane et al., 2006; Zahra and George, 2002). Todorova and Durisin (2007) emphasize the value of external knowledge, arguing that acquisition is not an automatic process. On the one hand, firms may assimilate external knowledge readily if this is 'close' to their own knowledge structures or search zone. On the other hand, they may fail to identify useful knowledge, either because of cognitive biases and rigidities, or because the criteria used for evaluating external knowledge are tied to current market trends and neglect perceived future needs (Todorova and Durisin, 2007; Zahra and George, 2002)

Absorptive capacity has been described as a learning dyad that depends on establishing a match in the relative characteristics of partner firms (Dyer and Singh, 1998). Grönroos and Voima (2013) describe interactions between service providers and their customer as "situations in which the interacting parties are involved in each other's practices" (p. 140). Both partners actively contribute to and influence the outcome of the exchanges occurring in the interaction (Grönroos and Voima, 2013). The interaction between business partners can serve as a route through which knowledge about innovative products and services is exchanged in B2B relations (Dyer and Singh, 1998; Liu and Zhang, 2014; Nyaga et al., 2010). The premise is that B2B interactions have an impact on innovation activity that firms would not be able to generate simply by using their internal capabilities (Dyer and Singh, 1998; Kotabe et al., 2003). The relations of firms across their supply chains can help bridge knowledge gaps such as when confronted with identifying solutions to environmental problems or when co-producing environmental innovations (Paulraj, 2011). In order to exploit linkages with external partners, firms need to mobilize specific capabilities that facilitate the transfer of information and 
146 knowledge (Dyer and Singh, 1998; Kotabe et al., 2003). These absorptive capabilities relate to

147 the knowledge sourcing and assimilation strategies that firms deploy in their interaction with 148 supply chain partners (Kotabe et al., 2003; Vachon and Klassen, 2008).

149 Following this perspective, the inter-organizational context becomes a key aspect to investigate absorptive capacity-building, in line with the arguments of Dyer and Singh (1998) and others

151 (Knoppen et al., 2011; Lane et al., 2006; Sáenz et al., 2014). Firms have been shown to exploit 152 B2B relations in order to implement environmental solutions and improve their environmental 153 performance (Fraj et a., 2013; Vachon and Klassen, 2008). In this study, we analyse elements 154 of the B2B interaction that facilitate the transfer of knowledge and resources about ecoinnovation between the partners (Kotabe et al., 2003). We focus on low-tech firms which unlike those in high tech sectors, undertake little R\&D and therefore have limited absorptive capacity 157 (Hirsch-Kreinsen, 2008; Spithoven et al., 2010). Thus low-tech industries are not typically the source of innovative technologies; rather firms rely on obtaining external knowledge about available technologies from third parties and integrating this into their own innovation processes (Hirsch-Kreinsen, 2008; Santamaria et al., 2009; Spithoven et al., 2010).

\subsection{The context of absorptive capacity in low-tech firms}

Low-tech firms seek to obtain external resources and knowledge to compensate for inherent weaknesses in their innovation capacity and to improve their innovation output (Alvarez and Iske, 2015; Moilanen et al., 2014). They have been shown to exploit external relations as a source of new knowledge and as a means of acquiring resources for development activities (Forsman, 2011). Focussing on the hotel industry, this study explores how low-tech service

167 firms mobilise B2B interactions to compensate for their limited capacity for eco-innovation.

There are several sources of knowledge that firms access through interactions with other firms in the market. A principal source of knowledge about technical innovation for low-tech firms 
comes from suppliers (Hervas-Oliver et al., 2011; Hirsch-Kreinsen, 2008). However, they may

collaborate with research entities including universities and research centres to support R\&Drelated activities such as technology road mapping and intelligence (Hervas-Oliver et al., 2011; Maietta, 2015; Spithoven et al., 2010). Studies of the innovation performance of hotels, in particular, have demonstrated the positive influence that external knowledge sources have on the firms' innovation activities, especially in relation to process and marketing innovations. Martínez-Pérez et al., (2019) show that hotels that maintain relations with external agents have greater access to exploratory knowledge, defined as new knowledge which is used to generate new ideas and for problem-solving. These relations are established with diverse actors including such tourism businesses as tour operators, as well as with institutional actors such as universities and other entities offering research and training activities in tourism-related areas (Marco-Lajara et al., 2018). Moreover, Thomas and Wood (2014) working with tourism firms and hotels highlight the importance of networks (of suppliers and other businesses in the value chain) and personalized channels as valuable sources of external knowledge. Nonetheless, hotels require absorptive capacity in order to exploit external knowledge and internalise it into business processes (Marco-Lajara et al., 2018; Martínez-Pérez et al., 2019).

A broad category of business-related knowledge beyond the original emphasis on the appropriation of R\&D knowledge is considered relevant to building absorptive capacity for innovation in low-tech industries. This includes knowledge related to managerial practices and production know-how (Lane et al., 2006); and that about the market and the range and quality of products and services (Hervas-Oliver et al., 2015). Knowledge can also be acquired through training and learning-by-doing (Freel, 2016). Low-tech firms generate knowledge inputs for

192 product and process innovations by combining knowledge about existing technologies or by integrating new elements into existing technologies (Alvarez and Iske, 2015; Santamaria et al., 
195 knowledge. Consultants have been shown to support the development of both product and 196 process innovations in low-tech firms (Santamaria et al., 2009) and can assist their clients in 197 building absorptive capacity within the context of market transactions, as will be discussed in 198 this study.

\subsection{Absorptive capacity for eco-innovation}

200 What characteristics of eco-innovations may pose specific challenges to firms and their 201 absorptive capacities? Integrating eco-innovations in core business activities requires firms to 202 develop a long-term vision and commitment towards an environmental strategy, which in turn 203 hinges on the presence of a culture for eco-innovation and an environmental capability (Bossle 204 et al., 2016; Chen et al., 2012). These internal factors together reflect a proactive stance i.e. one 205 where the firm will take the initiative and seize opportunities to develop eco-innovations (Chen 206 et al., 2012).

207 In practice, eco-innovation in many firms is usually undertaken as a one-off activity, rather 208 than reflecting a long-term commitment (Bossle et al., 2016). Hellström (2007) argues that 209 even in such circumstances, improvements could be considered radical - or as characterized by 210 a high degree of novelty - when they enable a "quantum leap to a higher level of environmental 211 performance" (p. 157) compared to that achieved with incumbent technologies and practices. 212 Additionally, Petruzzelli et al., (2011) note that eco-innovations are often characterised by a 213 higher degree of complexity compared to other innovations, since diverse knowledge bases are 214 required for example, knowledge about how to assimilate eco-innovations in different phases 215 of product lifecycles and processes and about their impact on various operational aspects such 216 as energy and water consumption and waste production. To improve their environmental 217 performance, firms are required to integrate environmentally-relevant knowledge with existing 218 knowledge concerning opportunities for new or improved products and processes (Bossle et 219 al., 2016; Hellstrom, 2007; Vachon and Klassen, 2008). Klewitz et al., (2012) for example, 
220 demonstrate how different levels of external support - obtained mainly from consultancies and

221 local authorities - contribute to building an absorptive capacity for eco-innovation in SMEs,

222 enabling them to integrate knowledge about sustainability practices into their business

223 operations.

225 Cohen and Levinthal (1990) argue that exploration and exploitation of knowledge constitute the essence of absorptive capacity. Such exploration and exploitation depend upon the firm's

receptiveness to environmentally-relevant knowledge, and an ability to assimilate this into its practices and routines (cf Todorova and Durisin, 2007). The present study will consider the interaction between KIBS and their clients, in order to analyze how such a capacity for ecoinnovation is developed (Cainelli et al., 2015; Vachon and Klassen, 2008).

\subsection{The KIBS-client interaction as a locus for absorptive capacity-building}

232

233

234

235

236

237

238

239

240

241

242

KIBS-client interactions involve the development and exchange of knowledge. The establishment of effective linkages between the firms influences the innovation outcome of their interaction (Miles, 2012; Tether and Tajar, 2008). KIBS interact with the client in the process of delivering a service which is a solution to a problem or challenge faced by the client (den Hertog, 2000; Miles, 2005). The nature of the interaction may range from simply sharing information about needs and expectations, to close co-operation in order to manage tensions and achieve both pre-set and emerging goals.

The service is coproduced, rather than being solely created by the KIBS firm; it is "delivered" through some degree of interaction between the professional service provider and the client. The degree of interaction between KIBS and their clients has been shown to influence the type of knowledge exchanged as well as the level of customisation of products and services developed. Accessing knowledge from a wide pool of external sources enhances exploratory 
245 learning (Ferreras-Méndez et al., 2016). However, the exchange of tacit knowledge becomes 246 more likely as the strength and duration of the ties with the client increases (Landry et al., 247 2012); and trust is a critical factor in promoting the transfer of this form of knowledge (Hu et 248 al., 2018).

250 Considerable resources are needed to develop client-specific solutions. KIBS need to have 251 access to a variety of knowledge sources and can establish strong cooperative 'ties' with 252 customers, especially when developing radically new solutions, such as new-to-market 253 innovations (Rodriguez et al., 2017). However, customised solutions are not always easily 254 replicated with different clients. In their analysis of the factors influencing the growth of small 255 KIBS firms in the Veneto region, Cabigiosu and Campagnolo (2019) demonstrate that 256 dedicating resources to develop customised solutions across a broad client base, may limit the 257 positive growth effects that KIBS reap from client-supplier relations. This may influence the 258 type of knowledge exchanged with business partners for the development of innovation and 259 the extent of collaboration between KIBS and their client (Miozzo et al., 2016). As a result, 260 KIBS may need to balance service customisation and standardisation, by managing resource 261 allocation and making careful decisions as to the breadth and scope of collaboration with their 262 clients.

KIBS firms provide expert advice, sharing information and specialist knowledge, and drawing on experience obtained from previous projects (Castaldi et al., 2013; den Hertog, 2000). They deliver valuable knowledge i.e. knowlege which may lead to innovation activities in the client.

267 However, clients also serve as a source of knowledge about new technologies and markets: 268 interaction with the client can be a significant route for KIBS to access valuable intelligence 269 when developing innovative solutions (Rodriguez et al., 2017). Nonetheless, clients are 
270 heterogeneous and need to be equipped with their own internal resources to engage in

271 knowledge transfer for innovation. Based on a study of the characteristics of enterprises

272 procuring KIBS activities in Northern Britain, Freel (2016) indicates that a precondition for

273 innovation-led cooperation with KIBS is the presence of resources that go beyond investments

274 in science and technology and include the availability of skills and expertise and workforce

275 training. Thus, KIBS firms need to recognize their clients' specific needs and gaps in know-

276 how in order to develop solutions - including diagnosis of what the problem is and the location

277 of relevant knowledge (Miles et al., 2019). KIBS may facilitate innovation processes within

278 the client-firms by stimulating access to new sources of information and new ideas and by

279 compensating for or strengthening the client's existing capabilities for innovation (Doloreux

280 and Shearmur, 2013; Miles, 2012; Tether and Tajar, 2008). Alternatively, they may act more

281 as carriers of innovations developed elsewhere, in other firms or industry settings (den Hertog,

282 2000).

283

284 Certain aspects of the KIBS-client interaction have been shown to influence the client's innovation performance. These include the KIBS' proximity to, and frequency of interaction with its client (Muller and Doloreux, 2009). The level of client commitment and trust can also be critical (Eisingerich et al., 2009; Hu et al., 2018). In a study of KIBS operating in the Canadian manufacturing sector, Doloreux and Shearmur (2013) demonstrate that clients utilizing different knowledge sourcing strategies from KIBS experience different innovation outcomes. An unfocused information seeking strategy enabled the implementation of product innovations in the client; whilst targeted knowledge and know-how sourcing strategies resulted in broader innovation outcomes in terms of the range of innovations implementing in the clientfirm. These aspects have often been studied independently by taking the perspective of one of the partners in the dyad. This study considers the perspectives of both partners and explores 
295 how two elements of the KIBS-client interaction influence the process of knowledge exchange

296 and absorptive capacity-building. One is the alignment of the partners' goals and objectives (in 297 our case, especially concerning environmental behaviour). Another element is the 298 compatibility of the partners' competencies to implement eco-innovations (Sáenz et al., 2014; 299 Sarkar et al., 2001).

\subsubsection{Alignment}

301 Achieving alignment around the goals and objectives of the business interaction is an important 302 element of interorganisational relations. It contributes to building cooperation amongst the 303 partners, and facilitates sharing of information and competences (Dekker, 2004). Alignment 304 may also involve the business partners' receptivity to and agreement on the value of external 305 knowledge sources for innovation, an intrinsic element of absorptive capacity (Todorova and 306 Durisin, 2007).

307

308 The degree of cognitive alignment between business partners is likely to influence the direction of search for new information and the way managers interpret and assimilate information within the organisation (Grandinetti, 2011; Nooteboom, 2000). Managers may vary in their perception of opportunities and problem-solving approaches. Helfat and Martin (2015) discuss the role that managers' prior knowledge has in decision-making, referring to how managers rely on familiar 'knowledge structures', be this technology- or industry-specific knowledge and firm-specific experience. Entities sharing cognitive proximity possess 'similar' knowledge bases facilitating knowledge exchange and learning (Boschma, 2005). Physical separation contributes to creating a cognitive distance between managers in KIBS and client-firms that has been shown to influence the mode of service delivery and the stages in the service delivery process in offshoring activities (Mol and Brandl, 2018). 
320 Cognitive alignment denotes how entities develop a 'shared' sense of the world in order to 321 achieve "a common goal" (Nooteboom, 2000:71). Beyond the purely cognitive elements, when

322 discussing strategic alliances, Dekker (2004) characterizes business partners with a 'good fit' 323 as those sharing a similar value system, in terms of what motivates them to perform the task at 324 hand. Alignment of organisational norms and values influences business relations by also 325 encouraging the exchange of skills and competencies that leads to successful execution of a 326 project (Sarkar et al., 2001). In the context of eco-innovation, the sharing of goals and values 327 that shape environmental behaviour in firms may be critical (Fraj et al., 2013). The role of top 328 managers in building an environmental vision and having internal stakeholders committed to 329 the firm's environmental strategy has been shown to facilitate the exploration of opportunities 330 (Chen et al., 2012). The corollary is that partners are 'mis-aligned' when driven by individual opportunism that prevails over a common need or objective. This generates mismatches in both the service provider and the client expectations and understanding of the roles that they need to play in order to implement a product or service solution (Dekker, 2004; Sjödin et al., 2016). Thus, the ways in which KIBS and their clients align objectives about a task at hand and the influences this has on the client's absorptive capacity to acquire and exploit knowledge about eco-innovation, are important topics to consider.

\subsubsection{Compatibility within the business interaction}

There can be different elements to describing partner compatibility within B2B interactions.

340 Nyaga et al., (2010) point to the need for business partners to develop a level of trust and commitment in buyer-supplier relations. In his study of professional services, Tordoir (1995) presupposes that only business partners having certain internal professional 'capacity' can adequately appropriate external professional services. This is congruent with the business partners sharing a level of similarity in their capabilities and competencies which has been 
345 shown to enhance the quality of B2B relations in terms of increasing the efficiency of project 346 execution (Sarkar et al., 2001). Different from resources that refer to the firm's tangible and 347 intangible assets, competencies describe how a firms utilises its resources to develop 348 organisational processes and routines to implement environmental strategies (del Río et al., 349 2016). Competencies can include the firms' technical capabilities, management skills and 350 organisational capacity and how these are deployed to acquire new information and assimilate 351 it within the organisation (Sarkar et al., 2001).

352 The above perspectives could underpin strategic elements such as the partner firms' openness to knowledge and learning about environmental practices that could influence absorptive 354 capacity (Liu and Zhang, 2014). Due to their professional competencies and experience, KIBS 355 are likely to take the lead in managing knowledge and competencies for innovation (Aarikka356 Stenroos and Jaakkola, 2012). However, the competencies of the client may also influence 357 knowledge exchanges with KIBS (Freel, 2016). For example Sjøholt (2001), interviewing both 358 transnational consultancy firms and their clients in Norway, concluded that more sophisticated 359 clients (those that had already accumulated knowledge helping them to absorb service inputs) 360 learned most from, and made most effective use of KIBS.

361 In B2B interactions, partners need to become familiar with each other's knowledge base, establishing "who knows what", in order to be able to leverage similar assets (Dyer and Singh, 1998: 665). KIBS transfer knowledge to the client by integrating knowledge from different domains in order to deliver innovative solutions, thus creating value for the client (Pina and Tether, 2016). In so doing, KIBS bridge between the generic knowledge pool, represented as different stocks of knowledge and the specific context of the client. Similarly, KIBS can decontextualize knowledge and the experience accumulated from a particular project with one client to develop new products with a new client. Potentially, these aspects of KIBS 
intervention support the assimilation and exploitation of external knowledge by the client-firm,

enhancing its absorptive capacity. However, absorptive capacity also rests on the client's

capability to integrate external knowledge with internal capabilities to implement innovative

solutions. Thus client-firms possessing internal capabilities - technical and organisational capabilities for eco-innovation - are better able at mobilising resources and learning from interaction with their business partner (Hofmann et al., 2012).

Another aspect is the business partners' organisational capacity to implement eco-innovations (Sáenz et al., 2014; Sarkar et al., 2001). Management support for issues around corporate social responsibility and sustainability more generally, which are reflected in the firm's environmental culture, can help build organisational capabilities for eco-innovation (Fraj et al., 2013; Hofmann et al., 2012). By investing in human resources through training programmes and fostering career development, managers stimulate employees to explore and pursue environmental solutions and integrate these into organisational practices (Chen et al., 2012;

Fraj et al., 2013). This organisational capacity contributes to generating a proactive behaviour towards eco-innovation and can influence the extent to which firms establish relations with other environmentally-responsible business suppliers and transform environmental values into specific actions (Fraj et al., 2013; Liu and Zhang, 2014; Pace, 2016).

386 Based on the above review, this study focuses on the extent to which partner alignment and 387 compatibility influence the process of knowledge exchange between KIBS and their clients 388 and contribute to absorptive capacity-building.

\subsection{Methodology}

Investigating absorptive capacity requires to assess how firms capture value from external 
393 the analysis of large-scale data that link absorptive capacity to specific measures of (eco-) 394 innovation activity and business performance more generally (Freel, 2016; Harris and Yan, 395 2018). Alternatively, a qualitative analysis, such as that used in this study, focuses on collecting 396 observations and developing descriptions about the processes through which firms incorporate 397 external knowledge into their own practices and operations and develop absorptive capacities 398 for eco-innovation. In this study, an interpretive approach was undertaken to obtain rich 399 descriptions about the elements characterising the KIBS-client interaction through the lens of 400 both the service provider and the client and how these influence absorptive capacity for eco401 innovation (Miles et al., 2014). With interaction a key focus for the study, matched pairs of 402 KIBS and clients, within a given sector or industry, were sought. We focussed on the 403 interaction between engineering consulting firms and tourism accommodation establishments 404 and elaborate below on the motivations for selecting this sampling frame.

\subsection{The client: tourism accommodation establishments}

406 As major tourism actors, accommodation establishments, in particular hotels, require inputs of 407 both natural resources (water and energy) as well as other materials in the form of food and 408 beverages, cleaning products etc. and generate such outputs as waste and emissions (Della 409 Volpi and Paulino, 2018). Hotels were considered a valid unit of analysis for a number of 410 reasons. First, the activities within hotels can have a significant impact on natural resource use

411 (Molina-Azorin et al., 2009); and through the management of these activities, hotels can help 412 preserve a destination's natural resources. Second, adopting environmental practices can be a 413 means for hotels to reduce their operational costs and improve performance thus providing a 414 source of competitive advantage (Molina-Azorin et al., 2009; Orfila-Sintes and Mattsson, 415 2009). The Mediterranean island of Malta is a convenient research setting, due to the island's 416 thriving tourism industry and the authors' knowledge of the local context. 
417 The selection of hotels was based on two main criteria concerning their environmental

418 behaviour. The first required the hotels to have adopted a national eco-certification, recognized

419 by the Global Sustainable Tourism Council, which assesses the hotel's environmental 420 performance based on key criteria including energy consumption, water and waste 421 management, and community engagement in sustainability initiatives. The second was that the 422 hotels had adopted innovative environmental measures thus providing cases for the study. The 423 empirical data showed that these innovations were mainly in energy and water technologies 424 and management practices.

425 Firm size is known to influence environmental behaviour (de Marchi and Grandinetti, 2013), 426 but this was not controlled for a priori: the 16 hotels sampled spanned a range of different sizes. 427 There was also variance in ownership structure, with the high-range hotels including 428 principally subsidiaries of multi-national groups. Appendix A provides an overview of the 429 hotels' profiles and competencies for eco-innovation.

$430 \quad 3.2$ KIBS: engineering and environmental services firms

431 Given the aim of studying KIBS that functioned as sources of environmentally-relevant 432 knowledge, we focused on engineering and environmental services firms. These are classified 433 within the environmental goods and services (EGS) sector supplying activities that limit or 434 prevent environmental damage and that contribute to more efficient use of natural resources 435 (Eurostat, 2016). This sector is diverse in the type of economic activities supported. It includes 436 firms that exclusively provide environmental services such as designing environmental 437 projects, risk and impact assessment, and the management of resources including water and 438 energy. Some firms are not purely "environmentally-oriented", while supplying combinations 439 of environmental, architectural and engineering services that support activities linked to 440 environmental protection and resource management such as environmental certification 
441 processes. The diversity of economic activities in the EGS sector makes it somewhat 442 problematic to map these to corresponding industry sectors. Generally, providers of 443 environmental-related services are included within the NACErev2 ${ }^{1}$ divisions M71, 444 architectural and engineering activities, and M74, other professional, scientific and technical 445 activities (Eurostat, 2016).

446 The 14 engineering consulting firms selected for this study were nominated by the 447 corresponding hotel-clients. In Appendix B, the profile of the firms is summarised, including 448 the market orientation and competencies for eco-innovation. The firms' profiles showed them 449 to constitute a mixed sample. Eight (E1-E8) were environmental services firms - specialised in 450 the provision of environmental management solutions. The other six (E9-E14) were building 451 services engineering firms which specialised in architectural and engineering activities 452 including the design and implementation of the facilities servicing the building (heating, 453 ventilation and air conditioning, HVAC systems), and incorporating environmental 454 management as part of their portfolio of services.

\section{$455 \quad 3.3$ Data Collection}

456 The study involved selecting pairs of KIBS and clients that were actively engaged in a business 457 relation. This purposive sampling approach enables study of "matched dyads" of knowledge 458 service providers and buyers (Nyaga et al., 2010). The hotels were asked to nominate 459 engineering consulting firm(s) which they contracted to oversee the 'facilities management' 460 function involving regular and continuous inspection and monitoring of operations; or which 461 they specifically engaged to implement environmental management services.

\footnotetext{
${ }^{1}$ NACE (Nomenclature of Economic Activities) is the European statistical classification of economic activities.
} 
462 The respondents selected for the semi-structured interviews were managers or directors from

463 both sides of the KIBS-client interaction who were directly involved in implementing eco-

464 innovations. The use of key informants, based on the informant's position in the organisation,

465 was considered the best way to obtain specialist and practical knowledge about absorptive

466 capacity-building (Bagozzi et al., 1991). 32 face-to-face semi-structured interviews, of average

467 duration 50 minutes, were conducted with senior partners and directors in 14 engineering

468 consulting firms and with general managers/directors or technical managers in 16 hotels. In

469 two of the hotels (H2 and H12), interviews were organized with both the general manager and

470 technical manager of the hotel.

471 The interview questions for the KIBS and the hotels broadly covered similar themes. The

472 interviewees were asked to share their experiences about the implementation of environmental

473 technologies and practices. They were asked about the decision-making process involved in

474 the adoption of such innovations, and the managers' level of expertise and knowledge and how

475 this developed within the firm; as well as the partners' respective roles in delivering

476 environmental solutions.

477 Obtaining responses from both sides of the KIBS-client dyad and from matched-pairs assured

478 the validity of the data and enabled us to triangulate key observations about absorptive capacity

479 for eco-innovation (Berg, 2007). Furthermore, we utilised online information and documents

480 about environmental initiatives implemented by the sampled firms to corroborate data obtained

481 from the interviews about environmental behaviour.

482

\subsection{Data analysis}

483 Firstly, for the thematic analysis, the principal dimensions characterizing the KIBS-client 484 interaction were derived from the literature reviewed in Section 2 and enriched with themes 485 from the interview data (Miles et al., 2014). For 'alignment', themes relating to the objectives 
486 and motives for implementing eco-innovations were identified across the matched dyads. For

487 'compatibility', aspects linked to the partners' competencies and capabilities to implement eco488 innovations were identified. Secondly, by matching the data from KIBS with data from the 489 corresponding hotel-clients, we sought to obtain a comprehensive analysis about how these 490 two aspects of the KIBS-client interaction influence absorptive capacity-building. Finally, by 491 looking across the dyads, we attempted to identify different patterns of KIBS-client interactions 492 (Berg, 2007; Miles et al., 2014). This interpretive phase forms the basis of the findings and 493 analysis in the next section.

\section{$494 \quad 4.0$ Findings \& Analysis}

495 The business interactions investigated between the engineering consulting firms and hotel496 clients concerned the provision of environmental and engineering services, focussing on 497 aspects related to energy saving and management, renewable energies and the management of water supplies. Table 1 identifies key elements of partner alignment and compatibility that 499 influence the KIBS-client interaction; these are discussed in the sections that follow. The scope 500 of the interaction ranged from the diagnosis and provision of pre-packaged solutions (such as 501 for monitoring energy consumption patterns and implementing waste management strategies), 502 to problem-solving and collaboration that often involved the co-production of environmental

503 solutions. As seen in Table 1, there were several instances where the same hotel was connected 504 with different engineering consulting firms.

$505-$ - insert Table 1 about here $\}$

506 The findings indicate a range of environmental behaviour in the hotel-clients based on an 507 assessment of their environmental profile and competencies for eco-innovation (refer to 508 Appendix A). The hotels with proactive environmental behaviours have a well-developed 509 environmental profile in terms of internal technical and organisational competences to 
510 implement eco-innovations; these are mainly mid- and high-range establishments. Hotels with

511 reactive environmental behaviours (low-range type) generally lack specific environmental

512 measures and possess limited competencies for eco-innovation. We focus our analysis on

513 understanding how the hotel-clients mobilise elements of their interaction with KIBS to

514 exchange knowledge about eco-innovation.

\section{$515 \quad 4.1$ Partner alignment around environmental objectives}

516 The findings reveal strategic, economic and functional objectives to be shaping environmental

517 behaviour. Table 2 illustrates how these dimensions were derived from the interview data and

518 provides interview excerpts that exemplify the key informants' perceptions for each of these

519 three dimensions. Achieving alignment along one or more of these different dimensions can

520 influence the outcome of a business interaction and, largely determines the extent to which the

521 partners' expectations from the interaction are fulfilled.

$522-\{$ insert Table 2 about here $\}$

523 4.1.1 Strategic alignment

524 One aspect of alignment is the firms' shared understanding about the strategic value of adopting 525 an environmental behaviour. For the hotel-client, this may be linked to delivering an 526 environmental standard as part of its corporate sustainability image or to conform to the 527 national eco-certification scheme - refer to interview excerpts from the H12-E9 dyad in Table 528 2. Partner alignment along strategic objectives has a positive influence on eliciting an open 529 search or exploration of environmentally-relevant knowledge by the client. The client (mainly 530 the high-range hotel type) is apt to explore opportunities to tap into the KIBS specialist 531 knowledge and exploit this in order to develop innovative environmental solutions. The 532 technical manager of a high-range hotel explained how: 
533 "We collaborated with an engineering firm to install a prototype system whereby $534 \quad$ treated water from our sewage treatment plant is purified to potable water standards. 535 We were also in contact with a German company that provided specialised membranes 536 for water purification; and the health department monitored the water quality to check $537 \quad$ it was of the required standard. The results seem to be encouraging." (H12)

538 KIBS firms with a mission to deliver environmental management solutions, mainly interact 539 with hotel-clients that share similar strategic objectives about environmental behaviour. These 540 are mainly environmental service firms (E1-E8) and a sub-group of building services engineers 541 (E9-E11). The development of innovative environmental services is often discussed in the 542 contract negotiation stage such as for new building developments or refurbishment projects, as 543 described by the senior partner of an environmental service firm:

"We approach clients whom we know are preparing tender documents for a new development, to gauge their interest in sustainable design, low carbon features etc...... We involve the [hotel] directors in visioning workshops and negotiate with them when discussing the feasibility of [environmental] projects." (E9)

548 Strategic alignment enables the KIBS firms to identify the client's needs and expectations in 549 the early stages of the service delivery process. This is more likely to enhance the assimilation 550 and exploration of specialist knowledge in the hotel-client and the development of customized 551 environmental solutions.

\subsubsection{Economic alignment}

553 A second aspect of alignment common across the range of firms sampled involves maximizing 554 the economic benefits from implementing environmental measures. The hotel sector is highly 555 competitive and largely driven by pricing strategies and narrow profit margins. Mid- to high556 range hotels link sustainability and environmental behaviour to a competitive advantage 
557 (Molina-Azorin et al., 2009). They demonstrate an enhanced ability to assimilate

558 environmentally-relevant knowledge, driven by a motivation to improve resource efficiency in

559 their operations and increase profit margins - refer to illustrative quotes from the H4-E11 dyad

560 in Table 2.

561 However, achieving alignment solely along the economic dimension affords for a narrower 562 range of exploration of environmental solutions, compared to when partners are aligned along 563 strategic objectives. In such instances, environmental behaviour is often limited to one-off 564 activities aimed at substituting existing equipment with resource-efficient alternatives that 565 reduce cost margins. The senior partner of an engineering consulting firm explained that:

"Energy efficiency is not a topic that we discuss regularly during routine monitoring of the [hotel facilities]. For example, the [hotel-]client will discuss with us fuel cost in a particular month and if this is high, the manager will tell me: let's look into this. We then need to see how to cut down on fuel cost which is essentially about cutting down on energy consumption." (E12)

571 From the KIBS perspective, the range of potential interventions is limited to instances where

572 the client, mainly the low-range hotel category, provides specifications for the introduction of 573 these interventions during routine monitoring and maintenance of the hotel's operations.

\section{$574 \quad$ 4.1.3 Functional alignment}

575 A third element of alignment is functional, concerned with achieving technical improvements

576 in the service delivery process. This dimension requires business partners to identify and 577 assimilate technical solutions for improving the efficiency of the service or modifying or 578 replacing equipment that enable aspects of service delivery. Interview excerpts from the H8-

579 E14 dyad in Table 2 are illustrative of functional alignment. Functional aspects of 
580 environmental practices are perceived with different levels of importance by the partners. An 581 example is reference to the use of "smart technologies" such as building management and smart 582 refrigeration systems for remote monitoring of resource consumption, which represent an 583 improvement over manual 'switch-on and switch-off' operations. Yet, the director of an 584 environmental services firm claimed that:

"The technical manager [in the hotel] has a system that he knows how to run and he is getting into a situation where he might have to install and work with a new system and new equipment that may need more attention and maintenance. So normally many, not

Misalignments may arise along the functional and economic dimensions that inhibit the client's capacity to assimilate and exploit environmentally-relevant knowledge for innovation. The owner of an environmental services firm explained how such misalignments may arise:

"Most chillers run at low efficiency and would need replacement in order to half the [energy] consumption in the hotel. However, hotels spend double to install photovoltaic systems rather than replacing inefficient chillers because they can get funding for the PV. My view is that first hotels need to install efficient equipment and then invest in renewables." (E1)

597 The engineering firms maintain links with different levels of management within the hotel598 client - in our study, with top managers (directors and general managers) and technical staff 599 (technical managers). The commitment of the client's top management appears crucial in 600 aligning the firm's strategic and economic goals about environmental behaviour with the 601 services provided by the KIBS firms. Strategic alignment is more likely to accelerate the 602 learning process within the client-firm, and to enhance exploitation of specialist knowledge 603 about eco-innovation. The engineering firms also interact with the client's technical staff along 
604 the functional dimension in order to exchange knowledge about innovative technological 605 applications as well as in organisational aspects e.g. those related to implementing an 606 environmental management strategy.

607

\subsection{Partner compatibility}

609 We explored the compatibility of business partners in terms of the level of similarity of their 610 resources and competencies to implement eco-innovation. Developing an absorptive capacity 611 for eco-innovation requires the client-firm to source and exploit broad types of resources and 612 competencies. As indicated in Table 1, the findings demonstrate that these include technical 613 resources about the implementation of innovative technological systems; organisational 614 competencies about the implementation of innovative environmental practices (e.g. 615 environmental management strategies and corporate social responsibility programmes) and 616 management support. Table 3 illustrates how these aspects of compatibility were derived from 617 the interview data.

$618-\{$ insert Table 3 about here $\}$

619 4.2.1 Developing competencies for eco-innovation

620 Environment-related information derives from diverse knowledge-bases related to engineering 621 and architecture, design and environmental management. 12 of the group of 14 engineering 622 firms sampled were members of professional networks where information and expertise about 623 eco-innovations is exchanged (refer to Appendix B). 10 of the engineering firms claimed that 624 their managers underwent formal training on environment and energy standards, as well as on625 the-job training about innovative technology applications such as on building energy 626 simulation models and eco-design modelling. 
627 Integrating eco-innovations in the hotel-client involves making various modifications in 628 operational activities. These include improvements in routine operations and engineering 629 activities (such as in the heating and ventilation systems). Broader organisational practices 630 related to awareness raising and training amongst employees are also significant. These 631 included new organization of management responsibilities in the back-office around achieving 632 environmental targets (e.g. for waste reduction and energy and water consumption - refer to 633 interview excerpts from the H7-E12 dyad in Table 3).

63413 out of the 16 hotels sampled (principally mid- and high-range hotels) provided training 635 opportunities for technical staff on environmental management systems and standards.

636 However, much of the environmentally-relevant competence in the hotel-client is obtained on 637 the job through a learning-by-doing approach. Thus, the environmental behaviour of the hotel638 clients relates to the capabilities of managers for learning and innovation. These include their 639 openness to explore external opportunities for eco-innovation, as well as to problem-solving 640 around environmental issues that enhance absorptive capacity. The technical manager of a mid641 range hotel explains that:

"In my previous job, I felt that the director was less ready to invest; and the job became too much of a routine, of doing the same thing. So I moved on. [In the current hotel], the Directors push for new projects to be implemented and are keen on making new investments which makes my job more dynamic and interesting. We have always had very good feedback from the Directors regarding investments in energy conservation and the staff is more motivated to work." (H5)

648 As illustrated above, the role of the top management in supporting environmental behaviour 649 enhances the opportunities of the technical staff to come forward with proposals to implement 650 environmental practices. This openness to exploring environmental solutions and to problem- 
651 solving increases the compatibility of technical competencies between the client with the

652 engineering firms and facilitates the exchange of technical knowledge about environmental

653 solutions - Table 3 provides illustrative quotations from the H14-E1 dyad. Low-range and a

654 portion of mid-range hotels, however, tend to be reactive when it comes to environmental

655 behaviour. In part this is because of restricted resources (mainly of qualified personnel).

656 Technical managers are less inclined to explore environmental solutions and to assimilate the

657 learning about eco-innovation from engineering consulting firms. Lack of an environmental

658 vision and support from the top management for implementing environmental practices leads

659 to low-range hotels implementing environmental solutions as one-off activities. This could also

660 have an impact on their environmental performance in the longer term.

\section{4.2.2 Deploying competencies for eco-innovation}

662 In the group of engineering firms sampled, environmental service firms (E1-E8) take up the 663 role of facilitating innovation in hotel-clients with proactive environmental behaviour. An 664 environmentally proactive client is better equipped with competencies to exploit KIBS' 665 specialist knowledge to implement eco-innovations. Shared problem-solving and 666 experimentation are conducive to the co-production of innovations and to mobilising client's 667 internal technical and organisational competencies as well as the skills and capabilities of KIBS 668 firms. A hotel owner described the process that went into designing a new hotel:

"I put together a team consisting of an international architectural firm, engineering and landscape consultants, interior designers, in what was really a collaborative approach to design resource conservation measures for the [new] hotel." (H12)

672 Building services engineering firms (E9-E14) mainly function as carriers of eco-innovation in

673 providing general environmental management support to their clients (a range of both high674 and low-range hotels). This support involves assimilating knowledge about compliance with 
675 environmental regulations such as on energy and waste management criteria and with 676 implementing the national eco-certification scheme - refer to interview excerpts from the H3677 E13 dyad in Table 3. A sub-group of innovative building services engineering firms (E9-E11) 678 are apt to explore innovative technology applications, such as energy simulation models and 679 eco-design methods, and to integrate these into engineering and architectural services. These 680 services are implemented in collaboration with clients that develop technical and organisational 681 competences to assimilate and exploit the engineering firms' knowledge in order to develop 682 environmental solutions.

683 Hotels with limited internal technical and organisational capacity are dependent on the KIBS 684 firms for sourcing specialist knowledge and competencies. Building services engineering firms 685 consider this type of client, mainly low-range hotels, to lack the competencies needed to 686 assimilate environmentally-relevant knowledge into their operations leaving a narrow corridor 687 for potential intervention. The senior partner in an engineering firm explains how:

"Some [hotels] would not normally have access to technologies for energy conservation or renewable energy technologies. They may not have the knowledge.... or they do their own thing without perhaps worrying about or thinking about energy consumption. [We] are specialized in this field and therefore we can do the job quicker, cheaper and better; we have the expertise to do just this in fact." (E12)

Management capabilities are deployed to support these clients in more practical aspects of implementing environment-related projects, such as obtaining funding support for the installation of renewable energy systems and fulfilling permitting requirements. The findings however demonstrate instances where KIBS interact with clients with limited technical capacity for eco-innovation (these were mid-range hotels), but which share similar strategic and functional objectives about environmental behaviour. In such instances (e.g. H8-E14 and 
699 H7-E12 dyads in Table 1), building services KIBS develop skills to support the client's 700 innovation process, compensating for the client's lack of technical competencies and enhancing

701 the client's exploration and assimilation of environmentally-relevant knowledge.

702

703

\subsection{An analysis of B2B interactions and their influence on absorptive capacity-building}

704 The findings concerning business partner alignment and compatibility point to further 705 understanding how B2B interactions influence absorptive capacity for eco-innovation. Figure 7061 links these partner attributes with the three dimensions of absorptive capacity, that refer to 707 the exploration, assimilation and exploitation of environmentally-relevant knowledge. The 708 model identifies combinations of partner attributes that give rise to different patterns of 709 interaction between KIBS and client-firms.

$710-\quad$ insert Figure 1 about here $\}$

711 Exploration of environmentally-relevant knowledge is contingent on the relative perspectives 712 of the partners about environmental behaviour. Strategic alignment about environmental 713 objectives impacts positively on the client's openness to exploring innovative environmental 714 solutions which is a key element in developing an absorptive capacity for eco-innovation. In 715 such instances, the KIBS-client interactions are highly collaborative and often characterized by 716 the co-creation of eco-innovations, mainly involving environmental services firms and 717 proactive clients.

718 When partner alignment is based mainly on identifying functional improvements and economic 719 gains from environmental performance, this results in a narrower search for environmental 720 solutions and limits the exchange of knowledge between the client and KIBS firms. In such 721 cases, the client (low and higher-rated hotels) engages in cooperative interactions with both 
722 building engineering services and environmental services firms. In the interaction, the client 723 may assimilate specialist knowledge from KIBS to implement incremental improvements in 724 operational efficiency rather than redeploy resources from core operations to develop 725 innovative environmental solutions. Although the search for eco-innovations is limited in 726 scope, the client effectively assimilates specialist knowledge, such as that relevant to upgrading 727 water and energy management systems, into its own operations.

728 Assimilating and exploiting knowledge for innovation requires the client to invest significant 729 resources for reorienting staff responsibilities and for managing the interaction with KIBS 730 firms. This implies that absorptive capacity hinges on the compatibility of the partners' 731 technical and organisational competencies and skills to implement eco-innovations. When the 732 competencies of the client do not match those in the KIBS firms (mainly the case for low-range 733 hotels), the client is unlikely to achieve significant improvements in environmental 734 performance through interaction with the KIBS. The KIBS firms in question (building 735 engineering services in our study) compensate for the client's limited absorptive capacity, by 736 providing advice and support on the performance of environmental technologies during the 737 course of more routine services.

\section{$738 \quad 5.0$ Discussion \& Conclusions}

739 This study investigated how B2B interactions are mobilised to build absorptive capacity for 740 eco-innovation. A dyadic perspective on the interaction is developed, considering the 741 perspectives of both KIBS and their clients in order to obtain deeper insights about how 742 elements of the interaction influence the client's absorptive capacity. These elements include 743 the alignment of the partners' objectives around environmental behaviour, and the compatibility of the partners' resources and competencies to implement eco-innovations. 
745 The context of a low-tech service sector, that of the hotel sector in the tourism industry, presents

746 a number of specificities: clients tend to be more reliant on external sources of knowledge about

747 environmental practices. In this study, KIBS were found to bridge gaps in basic knowledge

748 about eco-innovations and to facilitate knowledge transfer about innovative solutions. In

749 practice, the interaction with KIBS supports the client in dealing with the complexity associated

750 with adopting eco-innovations related to the broad knowledge base needed to integrate these

751 innovations into different aspects of the firm, including operational processes, new

752 management approaches and organisational practices (Chen et al., 2012; Hellström, 2007). In

753 addition, the client's absorptive capacity determines the extent to which the firm integrates this

754 knowledge into different aspects of its operations and routines; whilst generally lacking internal

755 capacity to develop innovative technologies itself.

7565.1 Building absorptive capacity for eco-innovation: the role of partner alignment and 757 compatibility

758 Adding to previous literature concerning structural and organisational influences on firms' 759 environmental performance, this study has considered how specific characteristics of business 760 interactions influence absorptive capacity for eco-innovation. Our findings support arguments 761 that both partners actively contribute to shaping knowledge exchanges about eco-innovation in 762 a B2B interaction (Knoppen et al., 2011; Lane et al., 2006). The study demonstrates that the 763 synergistic combination of attributes of the business partners - in this case, partner alignment 764 and compatibility - has an impact on absorptive capacity-building for eco-innovation in the 765 studied sample (Dyer and Singh, 1998; Grönroos and Voima, 2013; Kotabe et al., 2003). It 766 builds on Dyer and Singh (1998) who consider absorptive capacity as more than a sum of the 767 features of the two firms and adds relevance to the notion that fostering business partnerships 768 in the supply chain can be a route to building absorptive capacity for eco-innovation. In these 769 instances, it means identifying compatibility between business partners that in turn influences 
770 the pattern of client interaction with KIBS firms (Aarikka-Stenroos and Jaakkola, 2012; den

771 Hertog, 2000; Miles et al., 2019). Thus, whereas partner compatibility may be inherent in the

772 interaction, it needs to be managed by the firms in order to achieve goals for environmental

773 behaviour.

774 The literatures on innovation in services, and on the roles of KIBS, consider partner attributes 775 as central to influencing the KIBS-client interaction; they address, for the most part, how 776 complementary knowledge and resources affect innovation output or performance in the client 777 and KIBS firms (Ferreras-Méndez et al., 2016; Lane et al., 2006; Rodriguez et al., 2017).

778 However, the role of partner characteristics in influencing the client's absorptive capacity779 building is an aspect that has not gained sufficient attention in the context of research on eco780 innovation. The study contributes to further deconstructing the elements of the KIBS-client 781 interaction that influence absorptive capacity. It demonstrates how combined elements of the 782 KIBS-client relation give rise to different interaction patterns; which in turn have an impact on 783 absorptive capacity-building for eco-innovation. The KIBS-client interactions are 784 characterised by alignment along multiple objectives, since there are different perceptions 785 about the relevance of environmental behaviour. Strategic and functional alignment of partners 786 with shared competencies for eco-innovations results in collaborative interactions that enable 787 both partners to expand their range of competencies in environmental practices. In the B2B 788 interactions investigated in the sample, partner alignment along strategic objectives and 789 resource compatibility have a positive influence on enhancing exploratory learning and 790 absorptive capacity. The findings also indicate that clients with limited inherent competencies 791 for eco-innovation are able to engage in cooperative interactions with KIBS if there is strategic 792 and functional alignment of the partners' goals around environmental behaviour. In these cases, 793 KIBS support the client by facilitating access to specialist knowledge related to identifying 794 innovative technological opportunities which is assimilated in the firm to improve operational 
795 efficiency. The findings confirm the key role played by top managers in seeking to achieve

796 strategic alignments and in mobilizing inhouse resources to implement environmental

797 behaviour in collaboration with KIBS firms.

798 Compatibility of the partners' competencies and resources for eco-innovation is critical in

799 shifting the locus of the KIBS-client interaction - from simply assimilating knowledge in order 800 to implement improvements in resource efficiency, to engaging in exploitative learning 801 (Todorova and Durisin, 2007) that translates into innovative environmental behaviour. 802 Following from Vachon and Klassen (2008), the findings show that clients with internal 803 technical and organisational competencies to implement eco-innovations are able to assimilate 804 and exploit specialised knowledge to develop eco-innovations. Nonetheless, it takes significant 805 internal resources for clients to learn to exploit expert knowledge for innovation (Fraj et al., 806 2013; Freel, 2016). Indeed, not all clients are equally equipped with these resources, and 807 structural issues (related to size, human resources, training, and environmental orientation) 808 limit capacity-building. A low absorptive capacity, characterized by a focus on economic gains 809 from environmental behaviour over strategic and functional elements of the interaction, limits 810 the client's exploration and assimilation of expert knowledge. KIBS help compensate for the 811 client's limited absorptive capacity and support the client by sharing information in other 812 aspects such as management of a project and compliance to environmental regulations.

\section{$813 \quad 5.2$ Implications for managers and policy-makers}

814 The business partnerships investigated in this study involved managers from both the client 815 and KIBS firms who were dealing with various aspects of implementing operational and 816 management efficiency - their activities and interactions were not dedicated solely to eco817 innovation adoption. The practical implication of the conceptual approach applied in the case 818 investigated in this study indicates that, in order to better harness the benefits of B2B relations 
819 for eco-innovation, managers on both sides of the dyad should seek to better align their internal

820 competencies as well as their strategic and functional orientations for adopting environmental

821 measures. Firms on both sides can prioritize those B2B relations that support absorptive

822 capacity-building for eco-innovation. This means them being more selective, identifying

823 partners from whom they can accrue larger potential benefits in terms of accessing relevant

824 resources and competencies.

825 Managers in client-firms play a particularly pivotal role in fostering interactions with business partners. By paying greater attention to the choice of partnerships, based on signalling more strategic alignments, they may be better able to recognize opportunities for learning about ecoinnovation. In particular, hotel managers may need to focus on particular elements of absorptive capacity, to address specific weaknesses or gaps in the firm's capabilities for eco830 innovation, such as exploring innovation possibilities or assimilating environmentally-relevant knowledge within business operations (to stimulate transformative learning).

832 This study focused on technical managers in hotel services with responsibility for overseeing 833 the operations and on top managers (directors and general managers) occupying a strategic 834 position in decision-making about environmental behaviour. Technical managers are typically 835 dedicated to routine business operations in their interaction with KIBS and need to be 836 encouraged to engage with business partners on aspects of environmental management that go 837 beyond sourcing information about eco-efficiency to exploring opportunities to implement 838 innovative environmental management practices in hotel services. This could be achieved by 839 providing incentives to managers to explore opportunities for eco-innovation taken outside of 840 day-to-day functions, including through engagement with external partners. Moreover, there 841 need to be formal channels through which technicians and engineers are involved in strategic 842 decisions about the adoption of environmental innovations such as when designing new843 development and refurbishment projects. These mechanisms would help to better align the 
844 client-firm's environmental orientation with the firm's internal capabilities and resources to

845 implement environmental practices. They could also serve to identify resource gaps and assist

846 managers in recognizing the value of business partnerships based on immediate resource needs

847 for eco-innovation.

848 In turn, as KIBS firms give attention to the development of environmentally-related services,

849 they must develop not only technical capabilities to implement eco-solutions but also identify

850 new approaches to marketing these solutions as part of the portfolio of services they offer.

851 KIBS provide different levels of support for eco-innovation, and developing client solutions

852 can involve a considerable investment of resources. They need to manage resources

853 strategically, by balancing the depth and level of engagement with the client, such as in

854 deciding how far to deliver client-specific solutions or more standardized services (Cabigiosu

855 and Campagnolo, 2019; Ferreras-Méndez et al., 2016).

856 There are also policy implications of this analysis. Currently, policies that stimulate eco-

857 innovation adoption are mainly either supply-side measures, aimed at supporting the adoption

858 of eco-technologies, such as through the provision of grants, or diagnostic measures that aim

859 to generate useful information about resource efficiency, such as through the implementation

860 of an environmental audit. At the firm level, policies could target hotels with a low innovation

861 capacity, such as by supporting training for managers on relevant approaches to testing and

862 validating eco-technologies. By developing internal capabilities, hotels (and low-tech firms

863 more generally) develop enhanced absorptive capacities, becoming better equipped to engage

864 in cooperative relations with supply-chain partners on eco-innovation initiatives. Furthermore,

865 since specialised knowledge about eco-innovative solutions may not be readily accessible to

866 many hotels, policy measures could support cooperation with suitable knowledge sources and

867 external partners from which low-tech services such as hotels could reap benefit. 
868 At a sectoral level, policies could foster collaborations that are likely to have a significant 869 impact on enabling a transition to eco-innovation in a low-tech sector. This could be achieved, 870 for example, by designing cluster policies that promote specific collaborations amongst hotels 871 and business partners around new-to-market innovations, rather than distributing resources 872 across a broad range of eco-innovation initiatives that are unlikely to have more than a minimal 873 impact on capacity-building in the sector.

\section{$874 \quad 5.3$ Limitations and areas for further research}

875 The empirical study reveals interesting associations about eco-innovation adoption and the 876 interaction of knowledge intensive business service providers with their clients. Several 877 limitations should be noted, however. Our results may be highly contingent on the specific 878 context of the study, both in terms of the selection of the B2B interaction as well as the focus 879 on particular elements of this interaction (Hofmann et al., 2012; Vachon and Klassen, 2008). 880 Moreover, the small sample size, and the focus on specific aspects of eco-innovation, 881 principally these were innovations in business operations and practices, limit the inferences 882 drawn from this empirical study to a similar context of a low-tech sector implementing process 883 innovations. Further study, involving different types of firm structure and ownership and that 884 considers distinct cultural and policy contexts, is certainly in order. We expect partner attributes 885 to influence absorptive capacity in different types of B2B relations; and a broader analytical 886 lens that considers a range of service sectors and firm-relations in the supply chain could shed 887 light on absorptive capacity-building for eco-innovation in services more generally.

888 Many avenues for further research are suggested by the findings of this study. Further 889 dimensions of $\mathrm{B} 2 \mathrm{~B}$ interactions in the context of absorptive capacity-building for eco890 innovation is one topic that deserves further pursuit. One such is investigating the 891 complementarity of partner resources and therefore the unique skills and assets that each 
892 partner brings to the interaction that may be influencing absorptive capacity-building. Another

893 is understanding how the level of commitment characterizing these interactions and their

894 duration influence knowledge exchange. Multivariate analysis, using a larger sample and

895 controlling for firm size and sector, would allow us to examine multiple dimensions of B2B

896 interactions, and to assess their impacts on absorptive capacity-building for eco-innovation. In

897 particular, such analysis could identify those elements of B2B interactions that have most

898 significant (positive or negative) impacts on absorptive capacity. For example, a quantitative

899 approach could shed further light on the significance of our finding that client-firms with low

900 internal capacity for innovation, are able to engage in collaborative relations with KIBS when

901 the partners are aligned in terms of functional motives, and that such relations have a positive

902 influence on enhancing the client's absorptive capacity.

903 In the present study we made no distinction between degree of novelty of eco-innovations; our 904 analysis focussed on the characteristics of B2B interactions and how these influence absorptive 905 capacity-building. Future research could evaluate the influence of B2B interactions on the 906 adoption of different types of eco-innovations, distinguishing in particular between incremental 907 innovations and radical (and/or between new-to-firm and new-to-market) innovations.

908 The contribution of KIBS to more sustainable business practices is a topic of great practical 909 significance. Our focus on environmental engineering and related services could be 910 complemented by examination of a wide range of other business services - R\&D services, 911 waste management services, training, and others that could be making meaningful 912 contributions. Furthermore, interactions with other stakeholder groups, including equipment 913 suppliers, may be important for capacity-building. Business relationships may be more than 914 dyadic, and large projects often involve numerous partners. The addition of partners may aid 915 or problematise - knowledge exchanges and fruitful working arrangements. Study of how such 916 interchanges are best managed for eco-innovation would be valuable. It would also be relevant 
917 to analyse the mechanisms through which firms use experiences from previous business

918 interactions to recognize and exploit the value of environmentally-relevant knowledge when

919 establishing new partnerships.

\section{References}

921 Aarikka-Stenroos, L., Jaakkola, E. (2012) Value co-creation in knowledge intensive business

922 services: A dyadic perspective on the joint problem-solving process, Industrial Marketing 923 Management, 41, 15-26.

924 Alvarez, H., Iske, P. (2015) Internal capabilities and external knowledge sourcing for product 925 innovation in LMT SMEs, Journal of Innovation Management, 3(2), 55-70.

926 Bagozzi, R. P., Youjae, Y., \& Phillips, L. W. (1991) Assessing construct validity in 927 organizational research, Administrative Science Quarterly, 36(3), 421-458.

928 Berg, B. L. (2007) Qualitative Research Methods for the Social Sciences Sixth Edition, Pearson 929 International Edition: USA.

930 Boschma, R. (2005) Proximity and innovation: a critical assessment, Regional Studies, 39(1), $931 \quad 61-74$.

932 Bossle, M.B., Dutra de Barcellos, M., Marques Vieira, L., Loïc-Sauvée, L. (2016) The drivers 933 for adoption of eco-innovation, Journal of Cleaner Production, 113, 861-872.

934 Cabigiosu, A., Campagnolo, D. (2019) Innovation and growth in KIBS: the role of clients' 935 collaboration and service customisation, Industry and Innovation, 26(5), 592-618.

936 Cainelli, G., De Marchi, V., Grandinetti, R. (2015) Does the development of environmental 937 innovation require different resources? Evidence from Spanish manufacturing firms, Journal 938 of Cleaner Production, 94, 211-220. 
939 Cainelli, G., Mazzanti, M. (2013) Environmental innovations in services: manufacturing940 services integration and policy transmissions, Research Policy, 42, 1595- 1604.

941 Carrillo-Hermosilla, J., del Río, P., Könnölä, T. (2010) Diversity of eco-innovations: 942 Reflections from selected case studies, Journal of Cleaner Production, 18, 1073-1083.

943 Castaldi, C., Faber, J., Kishna, M. J. (2013) Co-innovation by KIBS in environmental services 944 - a knowledge-based perspective, International Journal of Innovation Management, 17(5), $945 \quad 1350020-135002017$.

946 Chen, Y.S., Chang, C. H., Wu, F.S. (2012) Origins of green innovations: the differences 947 between proactive and reactive green innovations, Management Decision, 5(3), 368-398.

948 Cohen, W. M., \& Levinthal, D. A. (1990) Absorptive capacity: A new perspective on learning 949 and innovation, Administrative Science Quarterly, 35(1), 128-152.

950 Dekker, H.C. (2004) Control of inter-organizational relationships: evidence on appropriation 951 concerns and coordination requirements, Accounting Organizations and Society, 29, 27-49.

952 De Marchi, V., Grandinetti, R. (2013) Knowledge strategies for environmental innovations: 953 the case of Italian manufacturing firms, Journal of Knowledge Management, 17(4), 569-582.

954 Del Río, P., Carrillo-Hermosilla, H., Könnölä, T., Bleda, M. (2016) Resources, capabilities and 955 competences for eco-innovation, Technological and Economic Development of Economy, $95622(2), 274-292$.

957 Del Río, P., Peñasco, C., \& Romero-Jordán, D. (2015) Distinctive Features of Environmental 958 Innovators: An Econometric Analysis, Bus. Strat. Env., 24, 361-385.

959 Della Volpi, Y., Paulino, S.R. (2018) The sustainability of services: Considerations on the 960 materiality of accommodation services from the concept of life cycle thinking, Journal of 961 Cleaner Production, 192(10), 327-334. 
962 Den Hertog, P. (2000) Knowledge intensive business services as co-producers of innovation,

963 International Journal of Innovation Management, 4(4), 491-528.

964 Díaz-García, C., Ángela González-Moreno, A., Sáez-Martínez, F.J. (2015) Eco-innovation: 965 insights from a literature review, Innovation: Management, Policy \& Practice, 17(1), 6-23.

966 Doloreux, D., Shearmur, R. (2013) Innovation Strategies: Are Knowledge-Intensive Business 967 Services just another source of information?, Industry and Innovation, 20(8), 719-738.

968 Dyer, J. H., Singh, H. (1998) The Relational view: cooperative strategy and sources of 969 interorganisational competitive advantage, The Academy of Management Review, 23(4), 660970679.

971 Eisenhardt, K.M., Martin, J.A. (2000) Dynamic capabilities: what are they? Strategic 972 Management Journal, 21(10-11), 1105-1121.

973 Eisingerich, A.B., Rubera, G., Seifert, M. (2009) Managing service innovation and 974 interorganizational relationships for firm performance to commit or diversify?, Journal of 975 Service Research, 11(4), 344-356.

976 Eurostat (2016) Environmental goods and services sector accounts manual, Publications Office 977 of the European Union: Luxembourg.

978 Ferreras-Méndez, J.L., Fernández-Mesa, A., Alegre, J. (2016) The relationship between 979 knowledge search strategies and absorptive capacity: A deeper look, Technovation, 54, 48-61.

980 Forsman, H. (2011) Innovation capacity and innovation development in small enterprises. A 981 comparison between the manufacturing and service sectors, Research Policy, 40, 739-750.

982 Fraj, E., Martínez, E., \& Matute, J. (2013) Green marketing in B2B organisations: an empirical 983 analysis from the natural-resource-based view of the firm, Journal of Business \& Industrial 984 Marketing, 28(5), 396-410. 
985 Freel, M., (2016) Knowledge-intensive business services users and uses: exploring the 986 propensity to innovation related cooperation with knowledge-intensive business services. In

987 Doloreux, D., Freel, M., Shearmur, R., (Eds.), Knowledge intensive business services: 988 geography and innovation (93-116), Routledge: New York.

989 Grandinetti, R. (2011) Local/global cognitive interfaces within industrial districts: an Italian 990 case study, The Learning Organization, 18(4), 301-312.

991 Gronroos, C., Voima, P. (2013) Critical service logic: making sense of value creation and co992 creation, Journal of the Academy of Marketing Science, 41(2), 133-150.

993 Harris, R., Yan, J. (2018) Measurement of absorptive capacity from an economics perspective: 994 definition, measurement and importance, Journal of Economic Surveys 0(0), 1-28.

995 Helfat, C.E., Martin, J.A. (2015) Dynamic managerial capabilities: review and assessment of 996 managerial impact on strategic change, Journal of Management, 41(5), 1281-1312.

997 Hellström, T. (2007) Dimensions of environmentally sustainable innovation: the structure of 998 eco-innovation concepts, Sust. Dev., 15, 148-15.

999 Hervas-Oliver, J.L., Sempere-Ripoll, F., Boronat-Moll, C., Rojas, R. (2015) Technological 1000 innovation without R\&D: unfolding the extra gains of management innovations on 1001 technological performance, Technology Analysis \& Strategic Management, 27(1) 19-38.

1002 Hervas-Oliver, J.L., Garrigos, J.A., Gil-Pechuan, I. (2011) Making sense of innovation by 1003 R\&D and non-R\&D innovators in low technology contexts: A forgotten lesson for 1004 policymakers, Technovation 31, 427-446.

1005 Hirsch-Kreinsen, H. (2008) Low-tech innovations, Industry and Innovation, 15(1), 19-43. 
1006 Hofmann, K. H., Theyel, G., Wood, C. H. (2012) Identifying firm capabilities as drivers of 1007 environmental management and sustainability practices - evidence from small and medium-

1008 sized manufacturers, Bus. Strat. Env., 21, 530-545.

1009 Hu, T.S., Cheng-Wei Yu, C.W., Chia, P.C. (2018) Knowledge exchange types and strategies 1010 on the innovation interactions between KIBS firms and their clients in Taiwan, Cogent 1011 Business \& Management, 5, 1-23.

1012 Klewitz, J., Zeyen, A., Hansen, E. G. (2012). Intermediaries driving eco-innovation in SMEs: 1013 a qualitative investigation, European Journal of Innovation Management, 15(4), 442-467.

1014 Knoppen, D., Sáenz, M.J., Johnston, D. A. (2011) Innovations in a relational context: 1015 mechanisms to connect learning processes of absorptive capacity, Management Learning, $1016 \quad 42(4) 419-438$.

1017 Kotabe, M., Martin, X., Domoto, H. (2003) Gaining from vertical partnerships: knowledge 1018 transfer, relationship duration, and supplier performance improvement in the US and Japanese 1019 automotive industries, Strateg. Manag. J., 24, 293-316.

1020 Landry, R., Amara N., Doloreux, D. (2012) Knowledge-exchange strategies between KIBS 1021 firms and their clients, The Service Industries Journal, 32(2), 291-320.

1022 Lane, P. J., Koka, B. R., Pathak, S. (2006) The reification of absorptive capacity: a critical 1023 review and rejuvenation of the construct, Acad. Manag. Rev., 31(4), 833-863.

1024 Liu, C. L., Zhang, Y. (2014) Learning process and capability formation in cross-border buyer1025 supplier relationships: a qualitative case study of Taiwanese technological firms, International 1026 Business Review, 23, 718-730.

1027 Maietta, O.W. (2015) Determinants of university-firm R\&D collaboration and its impact on 1028 innovation: a perspective from a low-tech industry, Research Policy 44, 1341-1359. 
1029 Marco-Lajara, B., Claver-Cortés, E., Úbeda-García, M., García-Lillo, F., Zaragoza-Sáez, P.C. 1030 (2018) The role of internal knowledge generation and external knowledge acquisition in tourist 1031 districts, Journal of Business Research https://doi.org/10.1016/j.jbusres.2018.12.045.

1032 Martínez-Pérez, A., Elche, E., García-Villaverde, P.M. (2019) From diversity of 1033 interorganizational relationships to radical innovation in tourism destination: The role of 1034 knowledge exploration, Journal of Destination Marketing \& Management, 11, 80-88.

1035 Miles, I.D., Belousova, V., Chichkanov, N. (2019) Knowledge intensive business services: 1036 innovation and occupations, Foresight, https://doi.org/10.1108/FS-11-2018-0091.

1037 Miles, I. (2012) KIBS and knowledge dynamics in client-supplier interaction. In Di Maria, E., 1038 Grandinetti, R., \& Di Bernardo, B. (Eds.), Exploring Knowledge-Intensive Business Services: 1039 Knowledge Management Strategies (13-34), Palgrave Macmillan: Hampshire.

1040 Miles, I. (2005) Services and the knowledge-based economy. In Tidd, J., \& Hull, F.N. (Eds.), 1041 Service Innovation: Organizational Responses to Technological Opportunities \& Market 1042 Imperatives (81-112), Imperial College Press: UK.

1043 Miles, M.B., Huberman, A. M., Saldana, J. (2014) Qualitative Data Analysis: A Methods 1044 Sourcebook Third Edition, SAGE: Thousand Oaks.

1045 Miozzo, M., Desyllas, P., Lee, H.F., Miles, I. (2016) Innovation collaboration and 1046 appropriability by knowledge-intensive business services firms, Research Policy, 45, 133710471351.

1048 Moilanen, M., Østbye, S., Woll, K. (2014) Non-R\&D SMEs: external knowledge, absorptive 1049 capacity and product innovation, Small Business Economics, 43, 447-462. 
1050 Mol, M.J., Brandl, K. (2018) Bridging what we know: The effect of cognitive distance on

1051 knowledge intensive business services produced offshore International Business Review, 27, $1052 \quad 669-677$.

1053 Molina-Azorin, J.F., Enrique Claver-Cortes, E., Pereira-Moliner, J., Tar1, J.J. (2009) 1054 Environmental practices and firm performance: an empirical analysis in the Spanish hotel 1055 industry, Journal of Cleaner Production, 17, 516-524.

1056 Muller, E., Doloreux, D. (2009) What We Should Know about Knowledge-Intensive Business 1057 Services Technology in Society 31, 64-72.

1058 Nooteboom B. (2000) Learning by Interaction: Absorptive capacity, cognitive distance and 1059 governance, Journal of Management and Governance, 4, 69-92.

1060 Nyaga, G. N., Whipple, J. M., Lynch, D. F. (2010) Examining supply chain relationships: Do 1061 buyer and supplier perspectives on collaborative relationships differ? Journal of Operations 1062 Management, 28, 101-114.

1063 Orfila-Sintes, F., Mattsson, J. (2009) Innovation behaviour in the hotel industry, Omega, 37(2), $1064380-394$.

1065 Pace, L. A. (2016) How do tourism firms innovate for sustainable energy consumption? A 1066 capabilities perspective on the adoption of energy efficiency in tourism accommodation 1067 establishments, Journal of Cleaner Production, 111, 409-420.

1068 Paulraj, A. (2011). Understanding the relationships between internal resources and capabilities, 1069 supply management and organizational sustainability. Journal of Supply Chain Management, 1070 1(47), 19-37. 
1071 Petruzzelli, A. M., Dangelico, R. M., Rotolo, D., Albino, V. (2011) Organizational factors and 1072 technological features in the development of green innovations: Evidence from patent analysis, 1073 Innovation: Management Policy and Practice, 13, 291-310.

1074 Pina, K., Tether, B. (2016) Towards understanding variety in knowledge intensive business 1075 services by distinguishing their knowledge bases, Research Policy, 45, 401-413.

1076 Rodriguez, M., Doloreux, D., Shearmur, R. (2017) Variety in external knowledge sourcing and 1077 innovation novelty: Evidence from the KIBS sector in Spain, Technovation, 68, 35-43.

1078 Sáenz, M. A., Revilla, E., Knoppen, D. (2014) Absorptive capacity in buyer-supplier 1079 relationships: empirical evidence of its mediating role, Journal of Supply Chain Management, $108050(2), 18-40$.

1081 Santamaria, L., Nietob, M-H., Barge-Gil, A. (2009) Beyond formal R\&D: Taking advantage 1082 of other sources of innovation in low- and medium-technology industries, Research Policy, $1083 \quad 38(3), 507-517$.

1084 Sarkar, M.B., Echambadi, R., Cavusgil, S.T., Tamer, A., Preet, S. (2001) The influence of 1085 complementarity, compatibility, and relationship capital on alliance performance, Journal of 1086 the Academy of Marketing Science, 29(4), 358-373

1087 Sjödin, D.R., Parida, V., Wincent, J., (2016) Value co-creation process of integrated product1088 services: Effect of role ambiguities and relational coping strategies, Industrial Marketing 1089 Management, 56, 108-119.

1090 Sjøholt, P. (2001) Transfer of managerial knowledge by business related services. Working 1091 Paper 247, Department of Geography, University of Bergen, Norway, 1-29.

1092 Spithoven, A., Clarysse, B., Knockaert, M. (2010) Building absorptive capacity to organise 1093 inbound open innovation in traditional industries, Technovation, 30, 130-141. 
2

1094 Tether, B. S., Tajar, A. (2008) Beyond industry-university links: sourcing knowledge for 1095 innovation from consultants, private research organizations and the public science-base, 1096 Research Policy, 37(6-7), 1079-1095.

1097 Thomas, R., Wood, E. (2014) Innovation in tourism: Re-conceptualising and measuring the 1098 absorptive capacity of the hotel sector, Tourism Management 45, 39-48.

1099 Todorova, G., Durisin, B. (2007) Absorptive capacity: valuing a reconceptualization, Academy 1100 of Management Review, 32(3), 774-786.

1101 Tordoir, P. P. (1995). The Professional Knowledge Economy: The Management and 1102 Integration of Professional Services in Business Organizations. The Netherlands: Kluwer 1103 Academic Publishers.

1104 Vachon, S., Klassen, R.D. (2008) Environmental management and manufacturing 1105 performance: The role of collaboration in the supply chain, Int. J. Production Economics, 111, $1106 \quad 299-315$.

1107 World Economic Forum (2017) The Travel \& Tourism Competitiveness Report: Paving the 1108 way for a more sustainable and inclusive future, 1-387.

1109 Zahra, S.A., George, G. (2002) Absorptive capacity: A review, reconceptualization, and 1110 extension, Academy of Management Review, 27(2), 185-203. 
Table 1: Findings on partner alignment and compatibility from the Matched Pairs of Hotel-clients $(\mathrm{H})$ and Engineering Consulting Firms (E)

\begin{tabular}{|c|c|c|c|c|c|c|}
\hline \multirow{2}{*}{ Matched Pairs } & \multicolumn{3}{|c|}{ Alignment } & \multicolumn{3}{|c|}{ Compatibility } \\
\hline & Strategic & Economic & Functional & $\begin{array}{c}\text { Technical } \\
\text { competences }\end{array}$ & $\begin{array}{c}\text { Organisational } \\
\text { competences }\end{array}$ & $\begin{array}{l}\text { Management } \\
\text { support }\end{array}$ \\
\hline H1-E12* & & $\mathrm{x}$ & & & & $\mathrm{x}$ \\
\hline H2-E10 & & $\mathrm{x}$ & $\mathrm{x}$ & & & $\mathrm{x}$ \\
\hline H2-E12 & & $\mathrm{x}$ & & & & $\mathrm{x}$ \\
\hline H3-E13 & & $\mathrm{x}$ & & & & $\mathrm{x}$ \\
\hline H4-E11 & & $\mathrm{x}$ & & $\mathrm{x}$ & & \\
\hline H4-E12 & & $\mathrm{x}$ & & $\mathrm{x}$ & & \\
\hline H5-E8 & & $\mathrm{x}$ & $\mathrm{x}$ & & $\mathrm{x}$ & \\
\hline H5-E12 & & $\mathrm{x}$ & & $\mathrm{x}$ & & $\mathrm{x}$ \\
\hline H6-E5 & & $\mathrm{x}$ & & $\mathrm{x}$ & & $\mathrm{x}$ \\
\hline H6-E7 & & $\mathrm{x}$ & $\mathrm{x}$ & $\mathrm{x}$ & $\mathrm{x}$ & \\
\hline H6-E10 & & $\mathrm{x}$ & Pre & $\mathrm{x}$ & $\mathrm{x}$ & \\
\hline H7-E12 & & $\mathrm{x}$ & $\mathrm{x}$ & & $\mathrm{x}$ & $\mathrm{x}$ \\
\hline H8-E14 & $\mathrm{x}$ & $\mathrm{x}$ & $\mathrm{x}$ & & & $\mathrm{x}$ \\
\hline H9-E13 & & $\mathrm{x}$ & $\mathrm{x}$ & $\mathrm{x}$ & & \\
\hline H10-E12 & & $\mathrm{x}$ & $\mathrm{x}$ & $\mathrm{x}$ & $\mathrm{x}$ & \\
\hline H11-E12 & & $\mathrm{x}$ & $\mathrm{x}$ & $\mathrm{x}$ & & \\
\hline H12-E1 & & $\mathrm{x}$ & & $\mathrm{x}$ & & \\
\hline H12-E3 & & $\mathrm{x}$ & $\mathrm{x}$ & $\mathrm{x}$ & & \\
\hline H12-E4 & & $\mathrm{x}$ & & $\mathrm{x}$ & & \\
\hline H12-E8 & $\mathrm{x}$ & $\mathrm{x}$ & $\mathrm{x}$ & $\mathrm{x}$ & $\mathrm{x}$ & \\
\hline H12-E9 & $\mathrm{x}$ & $\mathrm{x}$ & $\mathrm{x}$ & $\mathrm{x}$ & $\mathrm{x}$ & \\
\hline H12-E10 & $\mathrm{x}$ & $\mathrm{x}$ & $\mathrm{x}$ & $\mathrm{x}$ & $\mathrm{x}$ & \\
\hline H12-E11 & & $\mathrm{x}$ & $\mathrm{x}$ & $\mathrm{x}$ & re & \\
\hline H12-E13 & & $\mathrm{x}$ & $\mathrm{x}$ & $\mathrm{x}$ & & \\
\hline H13-E13 & & $\mathrm{x}$ & $\mathrm{x}$ & $\mathrm{x}$ & & $\mathrm{x}$ \\
\hline H14-E1 & $\mathrm{x}$ & $\mathrm{x}$ & $\mathrm{x}$ & $\mathrm{x}$ & $\mathrm{x}$ & \\
\hline H14-E3 & $\mathrm{x}$ & $\mathrm{x}$ & & $\mathrm{x}$ & & \\
\hline H14-E4 & & $\mathrm{x}$ & $\mathrm{x}$ & $\mathrm{x}$ & & 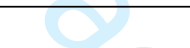 \\
\hline H14-E5 & & $\mathrm{x}$ & & $\mathrm{x}$ & & $\mathrm{x}$ \\
\hline H14-E6 & & $\mathrm{x}$ & & $\mathrm{x}$ & & \\
\hline H14-E8 & & $\mathrm{x}$ & $\mathrm{x}$ & $\mathrm{x}$ & $\mathrm{x}$ & \\
\hline H14-E9 & $\mathrm{x}$ & $\mathrm{x}$ & & $\mathrm{x}$ & $\mathrm{x}$ & \\
\hline H15-E2 & & $\mathrm{x}$ & $\mathrm{x}$ & $\mathrm{x}$ & & \\
\hline
\end{tabular}




\begin{tabular}{|l|c|c|c|c|c|c|}
\hline H15-E4 & & $\mathrm{x}$ & $\mathrm{x}$ & $\mathrm{x}$ & & \\
\hline H15-E9 & $\mathrm{x}$ & $\mathrm{x}$ & $\mathrm{x}$ & $\mathrm{x}$ & $\mathrm{x}$ & \\
\hline H15-E11 & & $\mathrm{x}$ & $\mathrm{x}$ & $\mathrm{x}$ & & $\mathrm{x}$ \\
\hline H16-E5 & & $\mathrm{x}$ & $\mathrm{x}$ & $\mathrm{x}$ & $\mathrm{x}$ & \\
\hline H16-E8 & & $\mathrm{x}$ & $\mathrm{x}$ & $\mathrm{x}$ & $\mathrm{x}$ & \\
\hline H16-E9 & $\mathrm{x}$ & $\mathrm{x}$ & & $\mathrm{x}$ & & \\
\hline
\end{tabular}

*H: hotel (code); E: engineering consulting firm (code). 
Table 2 - Dimensions of partner alignment that influence absorptive capacity-building

\begin{tabular}{|c|c|c|c|c|}
\hline \multirow[t]{2}{*}{ Dyads } & \multicolumn{2}{|c|}{ First-order themes describing partner alignment (illustrative quotes) } & \multirow{2}{*}{$\begin{array}{c}\text { Second-order (aggregated) } \\
\text { themes }\end{array}$} & \multirow{2}{*}{$\begin{array}{l}\text { Dimension of } \\
\text { partner } \\
\text { alignment }\end{array}$} \\
\hline & Hotel-Client (H) & Engineering Consulting Firm (E) & & \\
\hline H8-E14 & $\begin{array}{l}\text { "I believe that environmental issues and sustainability are } \\
\text { intrinsic components of the tourism product alongside a mix } \\
\text { of characteristics including beaches, safety, world heritage } \\
\text { sites etc." (Director, H12). } \\
\text { "I grew up in a resource-saving culture which reflects how I } \\
\text { manage the hotel. This culture has motivated in large part } \\
\text { the investments in energy saving technologies." (Director, } \\
\text { H8) }\end{array}$ & $\begin{array}{l}\text { "Companies need to show that they are green and doing } \\
\text { something for the environment. Basically my work } \\
\text { involves designing a tailored system for the client that } \\
\text { helps offset costs and meets the client's requirements." } \\
\text { (Senior partner, E9) } \\
\text { "Apart from cost considerations, having a green image is } \\
\text { one of the latest marketing trends." (Owner, E14) }\end{array}$ & $\begin{array}{l}\text { Shared objectives aimed at } \\
\text { building an environmental } \\
\text { standard/corporate image. }\end{array}$ & $\begin{array}{l}\text { Strategic } \\
\text { alignment }\end{array}$ \\
\hline H4-E11 & $\begin{array}{l}\text { "Investments in energy technology are high on the agenda; } \\
\text { since energy can 'make or break' our business.........The } \\
\text { audit carried out by the [engineering] consultants helped } \\
\text { raise awareness about measures to reduce resource } \\
\text { consumption." (Technical manager, H4) }\end{array}$ & $\begin{array}{l}\text { "Energy efficiency is not a new concept in the hospitality } \\
\text { industry. Ten to twelve years ago we weren't going green, } \\
\text { but we were very cost conscious. Today we are going } \\
\text { green. A good payback will stimulate client investment in } \\
\text { energy efficiency." (General manager, E11) }\end{array}$ & $\begin{array}{l}\text { Interventions driven by the goal } \\
\text { to reduce operational costs and } \\
\text { improve profit margins. }\end{array}$ & $\begin{array}{l}\text { Economic } \\
\text { alignment }\end{array}$ \\
\hline H16-E5 & $\begin{array}{l}\text { "Initially, we weren't sure whether the [innovative] water } \\
\text { heating system would perform up to the standard of the } \\
\text { more traditional solar water heating systems. And this was a } \\
\text { new system which had never been used locally; but we } \\
\text { listened to what the engineer was telling us about the } \\
\text { superior performance, and we went ahead." (Director, H8) } \\
\text { "When deciding which [energy] project to embark on finally } \\
\text { we look at the ability to save in cost. But the question also is } \\
\text { what are our priority needs: is it the change of glazing on the } \\
\text { windows? Is it about PVs? There are other priorities to } \\
\text { consider such as guest contact, smartness of hotel, and the } \\
\text { actual operation of the hotel." (Technical manager, H16) }\end{array}$ & $\begin{array}{l}\text { "Today a water chiller in a hotel consumes energy that is } \\
\text { equivalent to } 80 \% \text { of its capital cost in one year. So, the } \\
\text { capital cost is not the unique decision on which the client } \\
\text { bases a decision to invest. When we carry out an energy } \\
\text { feasibility study, we consider the running cost of } \\
\text { equipment over a number of years which becomes a major } \\
\text { consideration in the client's decision to invest." (Owner, } \\
\text { E14) } \\
\text { "We use smart metering systems to obtain the before and } \\
\text { after energy data and often find big problems [of energy } \\
\text { consumption]. This helps us compare different years of } \\
\text { consumption." (Director, E5) }\end{array}$ & $\begin{array}{l}\text { Shared goal to develop technical } \\
\text { improvements aimed at } \\
\text { enhancing resource efficiency in } \\
\text { the service delivery process. }\end{array}$ & $\begin{array}{l}\text { Functional } \\
\text { alignment }\end{array}$ \\
\hline
\end{tabular}


Table 3 - Dimensions of partner compatibility that influence absorptive capacity-building

\begin{tabular}{|c|c|c|c|c|}
\hline \multirow[t]{2}{*}{ Dyad } & \multicolumn{2}{|c|}{ First-order themes describing partner compatibility (illustrative quotes) } & \multirow{2}{*}{$\begin{array}{c}\text { Second-order } \\
\text { (aggregated) themes }\end{array}$} & \multirow{2}{*}{$\begin{array}{c}\text { Dimension of } \\
\text { partner } \\
\text { compatibility }\end{array}$} \\
\hline & Hotel-Client (H) & Engineering Consulting Firm (E) & & \\
\hline H14-E1 & $\begin{array}{l}\text { "We refer to specialised engineers and other consultancy } \\
\text { agencies when we require expertise on specific } \\
\text { [environmental] projects. For example, when assessing the } \\
\text { potential of installing combined heat and power we } \\
\text { worked with [E1] to determine the types of technologies } \\
\text { available on the market, how they operate, what difference } \\
\text { they would make for the hotel." (Technical manager, H14) }\end{array}$ & $\begin{array}{l}\text { "I am involved in a research project to develop domestic-scale } \\
\text { concentrated solar power for the generation of electricity and } \\
\text { water heating. Well, these are all existing technologies; it is } \\
\text { about trying to put together some improvements in } \\
\text { technologies. The trials will be carried out at hotel [H14]. I } \\
\text { know the management is very much into these activities and it } \\
\text { was like a natural course of things." (Owner, E1) }\end{array}$ & $\begin{array}{l}\text { Competencies to } \\
\text { implement innovative } \\
\text { technical solutions }\end{array}$ & $\begin{array}{c}\text { Technical } \\
\text { competencies }\end{array}$ \\
\hline H7-E12 & $\begin{array}{l}\text { "The aim of bringing all department representatives } \\
\text { together [as a green team] is because each department } \\
\text { tackles the environment issue from a different point of } \\
\text { view....... and every department has its own best practice } \\
\text { in terms of environment initiatives." (Director, H7) } \\
\text { "I was in property maintenance when I worked in } \\
\text { manufacturing in the UK and we already took care of } \\
\text { energy management at the time - that was } 15 \text { years ago. So } \\
\text { I started looking at energy management strategies in this } \\
\text { hotel a long time ago." (technical manager, H6) }\end{array}$ & $\begin{array}{l}\text { "The staff in a hotel changes quite fast....so this affects the } \\
\text { awareness on environmental issues. There needs to be constant } \\
\text { training. However, once you convince the directors that the } \\
\text { project is viable, they will go for it....also the technical staff } \\
\text { normally will look at change positively if they are improving on } \\
\text { current systems." (Senior partner, E12) } \\
\text { "I help hotels to also achieve the voluntary criteria for eco- } \\
\text { certification. For example, we assist the management in } \\
\text { communicating the environmental strategy to the staff by } \\
\text { making suggestions to reduce waste generation in the back- } \\
\text { office." (Owner, E7) }\end{array}$ & $\begin{array}{l}\text { Competencies to } \\
\text { develop innovative } \\
\text { organisational practices }\end{array}$ & $\begin{array}{l}\text { Organisational } \\
\text { competencies }\end{array}$ \\
\hline H3-E13 & $\begin{array}{l}\text { "Typically, we hear about upcoming measures such as the } \\
\text { eco-labelling scheme and the consultant interprets these } \\
\text { measures and tells us what needs to be done, for example, } \\
\text { whether there is need to replace particular equipment with } \\
\text { new eco-friendly equipment." (Director, H3) } \\
\text { "[E5] carried out an energy audit - the engineer gave me a } \\
\text { guarantee on the amount of savings that we'll have. Ok so } \\
\text { you have to do quite intensive energy consumption } \\
\text { calculations to evaluate choices for power saving } \\
\text { equipment." (Technical manager, H6) }\end{array}$ & $\begin{array}{l}\text { "Compliance with the national eco-label scheme requires firms } \\
\text { to monitor resource consumption. We typically undertake a } \\
\text { comprehensive [energy] audit and measure the energy loads and } \\
\text { lighting over a given period. Sometimes we find there are } \\
\text { clashes between the engineering knowledge and non-technical } \\
\text { knowledge such as when taking decisions about energy efficient } \\
\text { lighting." (Senior partner, E13) } \\
\text { "I do assist clients in preparing proposals for the energy grant } \\
\text { scheme. Sometimes the client goes for more than one } \\
\text { technological solution so it could be an energy saving solution } \\
\text { or a renewable energy installation; having more than one } \\
\text { solution makes the proposal more robust." (Director, E5) }\end{array}$ & $\begin{array}{l}\text { Competencies to assist } \\
\text { in compliance with } \\
\text { environmental targets } \\
\text { and regulations }\end{array}$ & $\begin{array}{l}\text { Management } \\
\text { support }\end{array}$ \\
\hline
\end{tabular}


Figure 1: Partner attributes and their influence on absorptive capacity-building for eco-innovation

\begin{tabular}{|c|c|c|c|c|}
\hline ALIGNMENT OF PARTNER MOTIVES & & ABSORPTIVE CAPACITY & & $\begin{array}{l}\text { COMPATIBILITY OF PARTNER } \\
\text { RESOURCES AND COMPETENCIES }\end{array}$ \\
\hline \multirow{2}{*}{$\begin{array}{l}\text { Harbouring strategic objectives } \\
\text { about environmental behaviour. }\end{array}$} & $\begin{array}{l}\text { Cooperative } \\
\text { interactions }\end{array}$ & \multirow{2}{*}{ Exploration } & $\begin{array}{c}\text { Information } \\
\text { exchange }\end{array}$ & \multirow{2}{*}{ 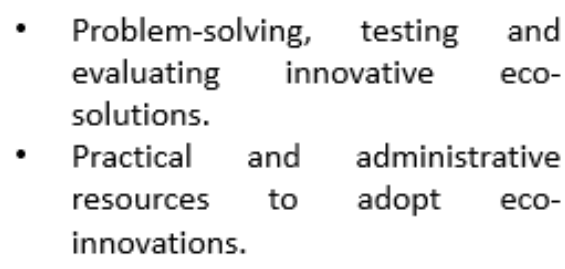 } \\
\hline & & & & \\
\hline $\begin{array}{l}\text { Maximizing economic returns } \\
\text { from eco-efficiency and eco- } \\
\text { innovation. } \\
\text { - Recognizing functional solutions to } \\
\text { enhance operational efficiency. }\end{array}$ & $\begin{array}{c}\text { Information } \\
\text { exchange/ }\end{array}$ & Assimilation & $\begin{array}{l}\text { Information } \\
\text { exchange/ } \\
\text { cooperative } \\
\text { interactions }\end{array}$ & $\begin{array}{l}\text { - Competencies for problem- } \\
\text { solving around enhancing } \\
\text { operational efficiency. } \\
\text { - Organisational competencies and } \\
\text { staff training on eco-solutions. }\end{array}$ \\
\hline $\begin{array}{l}\text { - Realising the strategic value of } \\
\text { eco-innovation. } \\
\text { Translating functional solutions for } \\
\text { enhanced efficiency in service } \\
\text { production and delivery. }\end{array}$ & $\begin{array}{l}\text { Collaborative } \\
\text { interactions }\end{array}$ & Exploitation & $\begin{array}{l}\text { Collaborative } \\
\text { interactions }\end{array}$ & $\begin{array}{l}\text { - Technical capacity to design and } \\
\text { implement innovative eco- } \\
\text { solutions. } \\
\text { - Training and on-the-job learning } \\
\text { about eco-solutions. }\end{array}$ \\
\hline
\end{tabular}




\section{Appendix A: Hotel-clients' environmental profile and competencies for environmental innovation}

\begin{tabular}{|c|c|c|c|}
\hline Theme & Description & Hotel Code & \\
\hline Hotel Category & $\begin{array}{l}\text { Low-range } \\
\text { (3-star rated) }\end{array}$ & $\begin{array}{l}\text { Mid-range } \\
\text { (4-star rated) }\end{array}$ & $\begin{array}{l}\text { High-range } \\
\text { (5-star rated) }\end{array}$ \\
\hline Hotels Sampled & $\mathrm{H} 1, \mathrm{H} 2, \mathrm{H} 3$ & $\begin{array}{l}\mathrm{H} 4, \mathrm{H} 5, \mathrm{H} 6, \mathrm{H} 7, \\
\mathrm{H} 8, \mathrm{H} 9, \mathrm{H} 10\end{array}$ & $\begin{array}{l}\text { H11, H12, H13, H14, } \\
\text { H15, H16 }\end{array}$ \\
\hline \multirow{4}{*}{$\begin{array}{l}\text { Environmental Measures } \\
\text { implemented }\end{array}$} & Lack specific environmental measures. & H4, H6 & \\
\hline & $\begin{array}{l}\text { Environmental measures implemented in guestroom (e.g. laundry reuse } \\
\text { policy; waste separation strategy). }\end{array}$ & H5, H9 & \\
\hline & Well-defined environmental mission statement and environmental policy. & $\mathrm{H} 7, \mathrm{H} 8, \mathrm{H} 10$ & H11, H15, H16 \\
\hline & Sustainability as a brand standard. & & $\mathrm{H} 12, \mathrm{H} 13, \mathrm{H} 14$ \\
\hline \multirow[t]{2}{*}{$\begin{array}{l}\text { Nature of service relation } \\
\text { with KIBS }\end{array}$} & $\begin{array}{l}\text { Project-based contracts for the evaluation, testing and implementation of } \\
\text { environmental technologies. }\end{array}$ & $\begin{array}{l}\text { H4, H5, H6, H7, } \\
\text { H9, H10 }\end{array}$ & $\begin{array}{l}\text { H11, H12, H13, H14, } \\
\text { H15, H16 }\end{array}$ \\
\hline & $\begin{array}{l}\text { Short- and long-term contracts to develop customised solutions, including } \\
\text { through co-creation with KIBS. }\end{array}$ & $\mathrm{H} 8, \mathrm{H} 10$ & $\begin{array}{l}\text { H11, H12, H13, H14, } \\
\text { H15, H16 }\end{array}$ \\
\hline \multirow{3}{*}{$\begin{array}{l}\text { Competences related to } \\
\text { implementing } \\
\text { environmental } \\
\text { technological innovations }\end{array}$} & 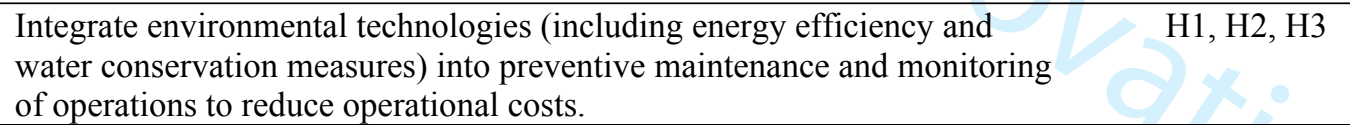 & $\begin{array}{l}\mathrm{H} 4, \mathrm{H} 5, \mathrm{H} 6, \mathrm{H} 7, \\
\mathrm{H} 8, \mathrm{H} 9\end{array}$ & $\begin{array}{l}\mathrm{H} 11, \mathrm{H} 12, \mathrm{H} 13, \mathrm{H} 14, \\
\mathrm{H} 15 \mathrm{H} 16\end{array}$ \\
\hline & $\begin{array}{l}\text { Design customized environmental technologies to improve efficiency of } \\
\text { business operations and contribute to the firm's environmental goals. }\end{array}$ & $\mathrm{H} 9, \mathrm{H} 10$ & H12, H13, H14, H15 \\
\hline & Research and development activities on environment-related projects. & & H11, H12, H14, H16 \\
\hline \multirow{4}{*}{$\begin{array}{l}\text { Competencies related to } \\
\text { implementing } \\
\text { environmental } \\
\text { organisational innovations }\end{array}$} & $\begin{array}{l}\text { Staff training on environment and/or energy systems and environmental } \\
\text { standards. }\end{array}$ & $\begin{array}{l}\text { H5, H6, H7, } \\
\text { H9, H10 }\end{array}$ & $\begin{array}{l}\text { H11, H12, H13, H14, } \\
\text { H15, H16 }\end{array}$ \\
\hline & Members of professional networks & $\mathrm{H} 5, \mathrm{H} 8$ & $\begin{array}{l}\mathrm{H} 11, \mathrm{H} 12, \mathrm{H} 13, \mathrm{H} 14, \\
\mathrm{H} 15, \mathrm{H} 16\end{array}$ \\
\hline & $\begin{array}{l}\text { Implement innovative organizational practices (e.g. waste management and } \\
\text { environmental strategy). }\end{array}$ & H6, H9, H10 & $\begin{array}{l}\mathrm{H} 11, \mathrm{H} 12, \mathrm{H} 13, \mathrm{H} 14, \\
\mathrm{H} 15, \mathrm{H} 16\end{array}$ \\
\hline & Inter-departmental committee/team for green affairs. & $\mathrm{H} 7, \mathrm{H} 10$ & $\begin{array}{l}\mathrm{H} 12, \mathrm{H} 13, \mathrm{H} 14, \mathrm{H} 15, \\
\text { H16 }\end{array}$ \\
\hline
\end{tabular}

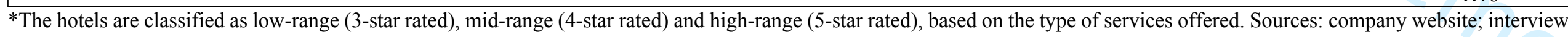
data; online media reports 


\section{Appendix B: Engineering consulting firms' environmental profile and competencies for environmental innovation}

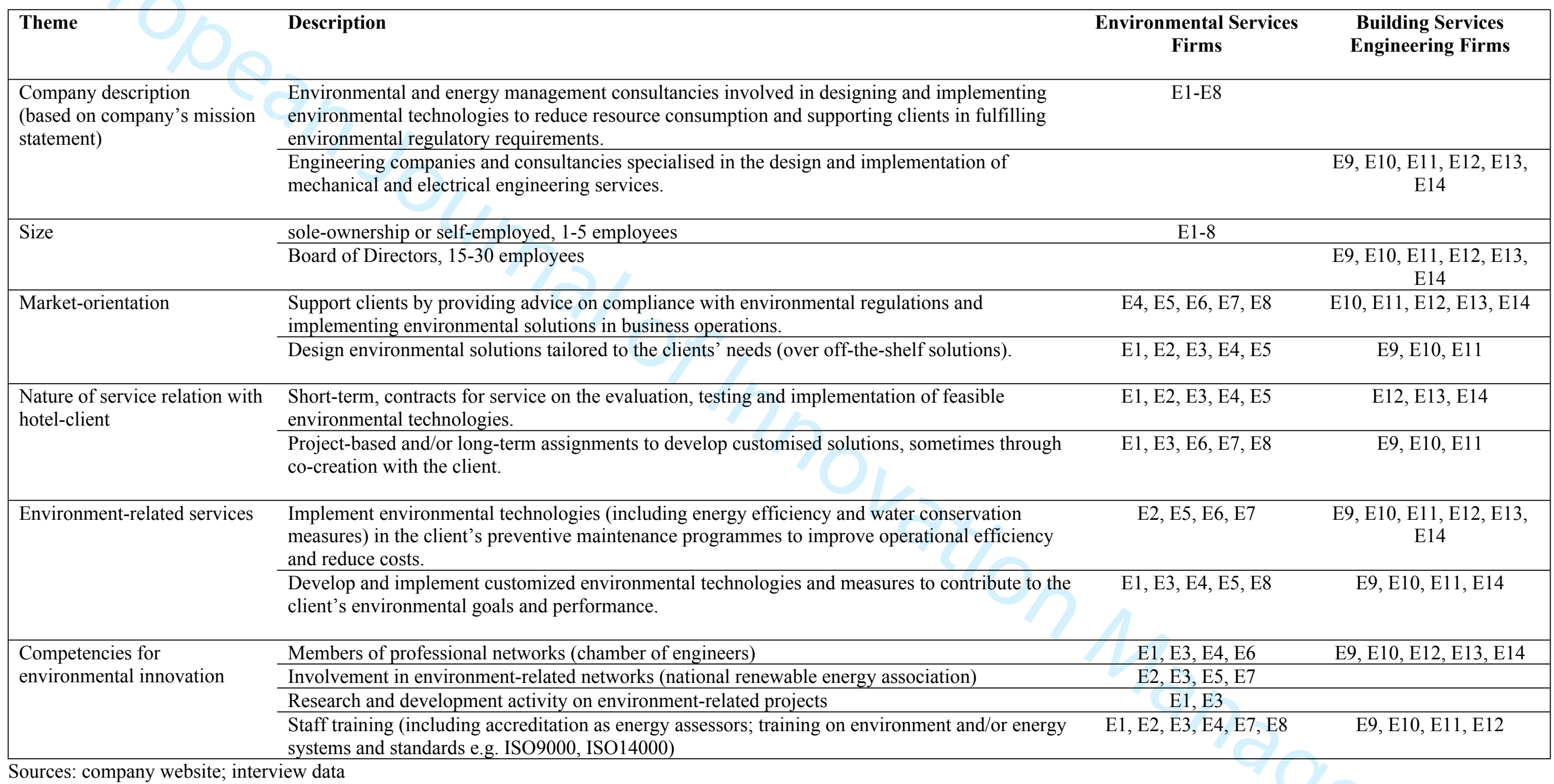

